\title{
Producción artística en la Baja Edad Media. Originalidad y/o copia
}

\author{
Olga Pérez Monzón* \\ Dpto. de Historia del Arte I (Medieval) \\ Universidad Complutense de Madrid \\ olgapmonzon@ghis.ucm.es
}

\begin{abstract}
RESUMEN
Durante el último período de la Edad Media, se produjo un notable incremento en la producción de objetos de arte. Este aumento cuantitativo fue posible por las dos formas de producción artística materializadas en el período: la obra por encargo realizada por artistas de reconocido prestigio y la producción estandarizada. Ambas coordenadas nos sitúan ante algunos aspectos a considerar en la puesta en valor de la obra de arte bajomedieval como el concepto de autoría y el de originalidad y/o copia.
\end{abstract}

Palabras clave: Baja Edad Media, producción estandarizada, contratos artísticos, originalidad, copia.

\begin{abstract}
During the last period of the Middle Ages, there was a marked increase in the production of art objects. This quantitative increase was made possible by the two forms of artistic production materialized in the period: the commissioned work by renowned artists and standardized production. Both coordinates put us in some aspects to consider in valuing the work of late medieval art as the concept of authorship and the originality and / or copy one.
\end{abstract}

Keys words: Middle Ages, standardized production, artistic contracts, originality, copy.

\section{Demanda de objetos de arte}

Durante los siglos bajomedievales se produjo un notable incremento en la producción de objetos de arte ${ }^{1}$. La primera reflexión, por tanto, que cabe hacerse es a qué obedeció tal circunstancia. Y la respuesta nos sitúa en los parámetros del uso antropológico de la imagen ya que tal demanda satisfizo una motivación variada que incluía desde la afición coleccionista de las clases distinguidas de la sociedad

\footnotetext{
Quiero dedicar este trabajo a mi maestra la profesora Aurora Ruiz Mateos con admiración, gratitud y un profundo cariño. El estudio se integra en el marco de los proyectos de investigación I+D+I: Prácticas de consenso y de pacto e instrumentos de representación en la cultura política castellana (siglos XIII al XV) (HAR2010-16762) y La génesis del Estado Moderno y el palacio especializado: Castilla y Granada en la Baja Edad Media (HAR2009-08901).

1 Recientes trabajos han centrado su análisis en la interrelación existente en torno a los vectores producción-clientela-mercado artístico. Como libro de referencia citamos el texto de M. MIQUEL JUAN, Retablos, prestigio y dinero. Talleres y mercado de pintura en la Valencia del gótico internacional, Valencia, 2008.
} 
a unos asentados usos religiosos vinculados, en buena medida, a la práctica de la devotio moderna.

Esta forma de devoción íntima y personal tuvo una notable incidencia en el universo artístico de la época. Su contribución fue decisiva en el desarrollo de los libros de horas que, como evocamos en numerosos testimonios contemporáneos, de forma harto frecuente aparecen incorporados al attrezzo nobiliar. En el Retablo de los Ángeles (1455. Colección Duque del Infantado), el marqués de Santillana posa con su libro cerrado sobre el oratorio ${ }^{2}$; por el contrario, María de Borgoña lo sostiene entre sus manos (miniatura de María de Borgoña en oración, Libro de horas de María de Borgoña, ca. 1470-1480)32. Las páginas abiertas del manuscrito permiten intuir las ilustraciones que lo ornamentan. Los libros de horas eran textos

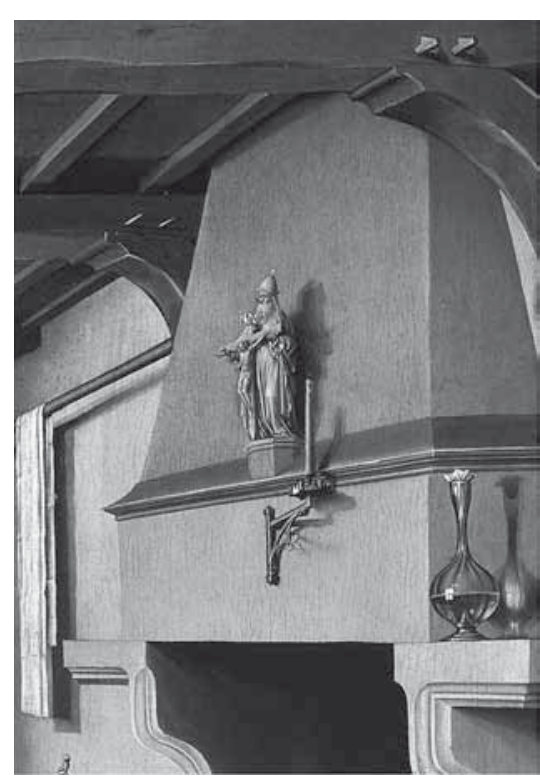

Fig. 1. Robert Campin, Santa Bárbara, 1438, detalle de la imagen de la Trinidad colocada sobre la chimenea (Museo del Prado, Madrid). de oración pero también de lujo y ostentación, al alcance sólo de unos pocos privilegiados.

El ejercicio de estos usos religiosos incidió asimismo en el ornato de los hogares. Objetos domésticos de heterogénea constitución material solían distribuirse bien en las habitaciones de uso comunitario y de función más pública, bien en los ámbitos más privados de los dormitorios. Convivían con el mobiliario dispuestos directamente en las paredes, entre el doselaje de las camas o sobre la armadura de las chimeneas. El Joven hombre en un interior (ca. 1450-60. National Gallery, London) de Petrus Christus o las obras atribuidas a Robert Campin dedicadas a la Anunciación (c. 1420. Museé Beaux-Arts de Bruxelles) y a Santa Bárbara (1438. Museo del Prado, Madrid) (fig. 1) ilustran estos aspectos ${ }^{4}$. En el primer caso, el anónimo retratado posa ante un grabado cristológico colgado en la pared; mientras que en las obras del citado maestro flamenco sendas imágenes de San Cristóbal ${ }^{5}$ o la

2 El análisis de esta obra en P. SILVA MAROTO, "El arte en España en la época del primer Marqués de Santillana (1398-1458)", El Marqués de Santillana 1398-1458. El Humanista, Hondarribia, 2001, pp. 155191; y J. YARZA LUACES, La nobleza ante el rey. Los grandes linajes castellanos y el arte en el siglo XV, Madrid, 2003a, pp. 223-224.

3 Este espléndido manuscrito ha sido estudiado por J.G. ALEXANDER, The master of Mary of Burgundy: a book of hours of Engelbert of Nassau, New York, 1970.

4 Sobre la problemática personalidad del maestro remitimos al trabajo de F. THÜRLEMAN, Robert Campin. A monographical study with critical catalogue, New York, 2002.

5 No debe pasar desapercibida la consonancia temática de esta secuencia hagiográfica con una de las xilografías devocionales más antiguas que se conservan dedicada a este popular santo medieval (San Cristó- 
Trinidad presiden la chimenea. También, podían conformar un símil de oratorios privados mediante tabernáculos de madera de alas abatibles y/o cortinas desplegables sostenidas por pértigas. El relieve alabastrino londinense de la Anunciación y la Trinidad (ca.1400. Victoria \& Albert Museum, A 193-1946) ${ }^{6}$ o el grabado de Martin Shongaüer María como templo virgen (Wien, Grapphische Samsung Albertina, Inv. 1926/697) visualizan estas prácticas, a la par que corroboran la acepción del oratorio no tanto como un espacio arquitectónico definido sino como un lugar devocional de carácter transportable. En las moradas más modestas, las estampas contentaron esta demanda piadosa.

Los textos, igual que las imágenes, nos ilustran sobre la cultura visual del período. Particularmente interesantes en este sentido fueron las medidas que los Reyes Católicos, por recomendación de Hernando de Talavera, tomaron en relación con la ciudad de Sevilla, al disponer que las casas tuviesen imágenes de Cristo, la Virgen o los santos con el objetivo -y ese es el elemento que nos interesa destacar- de favorecer la devoción:

"Item porque es cosa razonable que las casas de los fieles cristianos sean munidas y guardadas de la memoria de la pasión de nuestro Redentor Jesucristo y de su bendita madre, queremos y ordenamos que cada fiel cristiano tenga en la casa de su morada alguna imagen pintada de la cruz, en que nuestro señor Jesucristo padeció, y algunas imágenes pintadas de nuestra Señora o de algunos santos y santas que provoquen y despierten a los que allí moran a haber devoción"7.

La recomendación regia está ligada al viejo topos medieval del sentido docente de las imágenes y, por extensión, a su empleo como herramienta de evangelización. El proceso ha sido estudiado en el reino de Granada tras la conquista de los Reyes Católicos ${ }^{8}$. De forma paralela a otras actuaciones, para la política de conversión masiva de la población morisca se acudió a "representaciones santas y devotas" -probablemente un símil de dramas litúrgicos-y al uso de estampas que se entregaban a la población o se exhibían en los sermones ${ }^{9}$. Cotejamos lo extendido de tales prácticas en el desarrollo que, en el último período del Medievo, alcanzó el tema iconográfico

bal, 1423). Para completar, J. CHIPPS SMITH, "Prints and Printmaking", Northern Renaissance, London, 2004, pp. 239-272.

6 Obras contemporáneas como la Anunciación de Joos van Cleve (c. 1525. Metropolitan Museum of Art, New York) recuperan la colocación de estos oratorios en la arquitectura doméstica.

7 FRAY HERNANDO DE TALAVERA, Católica Impugnación, F. MÁRQUEZ y F. MARTÍN HERNÁNDEZ (ed.), Barcelona, 1961, cap. 53, p. 186.

8 Las mezquitas, ahora convertidas en iglesias, necesitaron notables cantidades de ornamentos, retablos y esculturas conseguidas, en buena medida, gracias a la producción seriada. La demanda artística provocada por los reinos recién conquistados en A. RUIZ MATEOS, O. PÉREZ MONZÓN y J. ESPINO NUÑO, "Las manifestaciones artísticas", J.M. NIETO SORIA (coord.), Orígenes de la monarquía hispánica: propaganda y legitimación (ca. 1400-1525), Madrid, 1999, pp. 357-360.

9 El hecho no fue excepcional, también en Alemania se emplearon estampas con fines pastorales. Cit. J. HAMBURGER, The visual and the visionary. Art and female spirituality in Late Medieval Germany, New York, 1998, pp. 322-332. El análisis de este proceso en F. PEREDA, Las imágenes de la discordia. Política y poética de la imagen sagrada en la España del 400, Madrid, 2007, p. 270. 


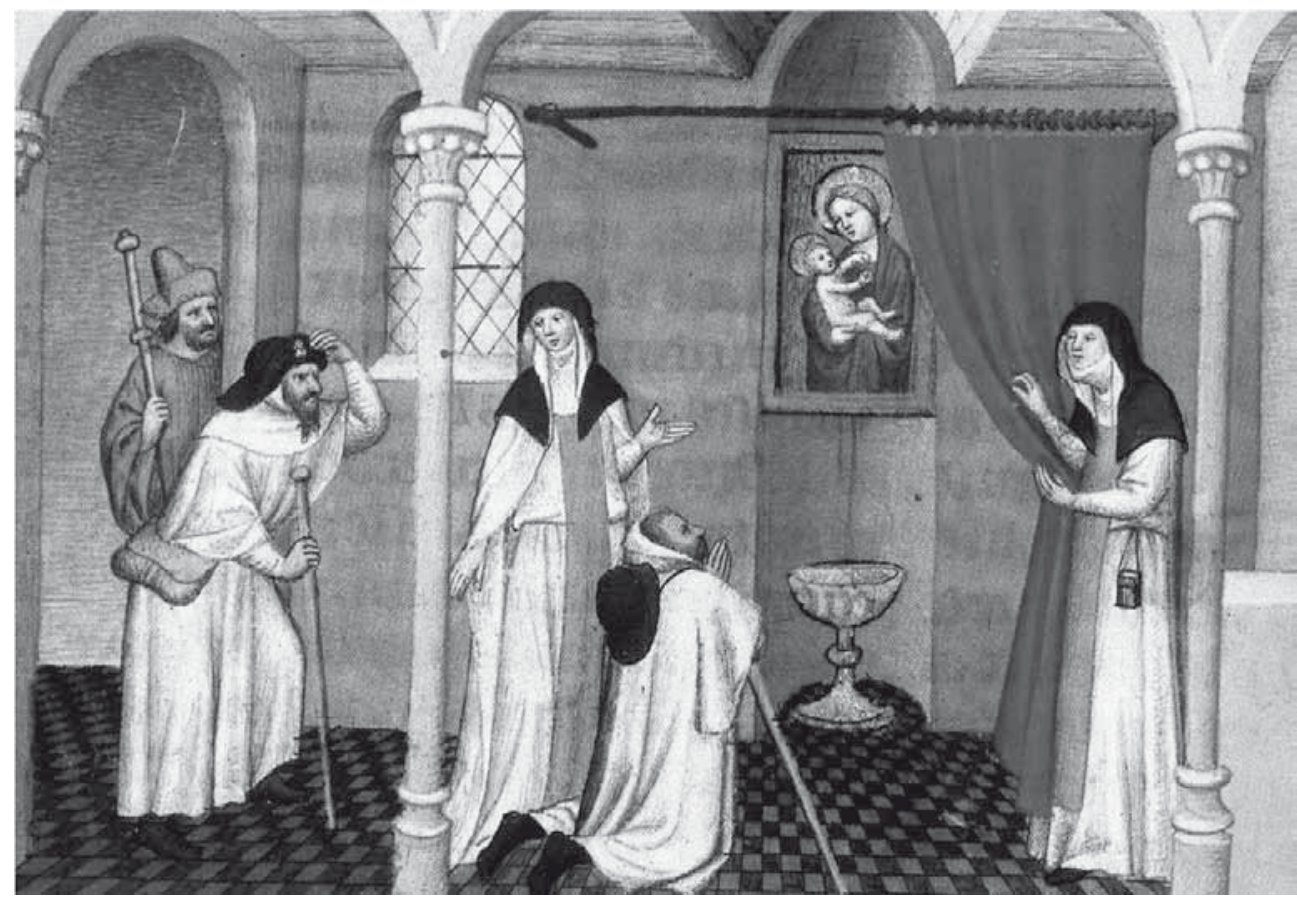

Fig: 2. Maestro de las Horas del Mariscal Boucicaut, Miracles de Nôtre Dame di Gautier de Coincy, Peregrinación al santuario de Saidnaya, ca. 1411-1412 (Bibliothèque Nationale, París. Fa. 2810, fol. 171v).

de la predicación ${ }^{10}$. La tabla del Maestro de la vista de Santa Gúdula titulada Predicación de San Vicente Ferrer y la Ascensión de Cristo (ca.1470-1490. Convento de PP. Dominicos Las Caldas de Besaya, Cantabria) constata de forma clara estos usos; apreciemos que a los convencionalismos característicos de estas escenas -púlpito, variada multitud o fiel somnoliento-, el artífice añadió el enarbolado por parte del santo de una imagen de temática apocalíptica. Con toda probabilidad, según interpretamos plásticamente, la prédica del santo debía versar sobre el citado tema bíblico ${ }^{11}$.

La imagen sagrada también fue empleada como promoción de santuarios y medio para favorecer el desarrollo de las peregrinaciones ${ }^{12}$. El devoto gustaba acudir al tem-

10 El prelado Jerónimo de Madrid, en sus predicaciones en las Alpujarras, llevaba "imáxines de papel y dávalas a todos quantos no las tenían y enseñávales como las avían de tener onradas y reverenciadas". Completa esa información el testimonio de Estanislao Colono sobre la impresión de cincuenta mil verónicas en pergamino por encargo del obispo de Jaén en octubre de 1493. Cit. F. PEREDA, op. cit., pp. 270 y 273.

11 El estudio particularizado de la tabla en M. ARIAS MARTÍNEZ, "Predicación de san Vicente Ferrer y Ascensión de Cristo", Comercio, mercado y economía en tiempos de la reina Isabel, Museo de las Ferias, Medina del Campo, 2004, pp. 132-134.

12 Diserta sobre el proceso cultual relativo a la Virgen de Guadalupe F. CRÉMOUX, "Las imágenes devocionales y sus usos. El culto a la Virgen de Guadalupe (1500-1570)”, M.C. DE CARLOS, P. CIVIL, F. PEREDA y C. VINCENT-CASSY (eds.), La imagen religiosa en la monarquía hispánica, Madrid, 2008, p. 62. 
plo a ver y, si era posible, tocar el icono venerado. Lo ratifican numerosos testimonios de la época como la miniatura realizada por el maestro de las Horas del Mariscal Boucicaut dedicada al santuario sirio de Saidnaya. (Peregrinación al santuario de Saidnaya, ca. 1411-1412. Miracles de Nôtre Dame di Gautier de Coincy) (fig. 2). La fama de su imagen mariana, de la que según contaba la leyenda emanaba un aceite prodigioso, significó la visita de cientos de peregrinos como, de forma expresa, se representa en la tabla. Mas este acto -la visita- sólo ocurría en puntuales ocasiones. Para facilitar su contemplación prolongada, los santuarios optaron por reproducir las imágenes veneradas en diferentes soportes y formatos como estampas, medallas o cintas. Estas reproducciones contribuían a propagar el culto y, por consiguiente, a difundir la fama del centro devocional ${ }^{13}$. Pocos ejemplos tan claros como el grabado sobre la iglesia de Ratisbona de Michael Ostendorfer (El camino del peregrino a la "Schöne Maria" de Ratisbona, ca. 1520, Kunstsammlungen der Veste Coburg) ${ }^{14}$. La imagen de la Virgen, considerada milagrosa, fue vendida masivamente entre los devotos conservándose los moldes de arcilla que facilitaron la consecución de réplicas (Moldes para sacar reproducciones distintas de la Schöne María de Ratisbona. 1519, Bayerische Nationalmuseum, Munich). Los ejemplos son numerosos y las circunstancias dispares. De tal modo, venerar el Arca de santa Úrsula de Hans Memling (1489, Museè, Bruges) el día de su festividad -21 de octubre- aseguraba 40 días de indulgencia; mientras que una obra como el Pozo de Moisés de la Cartuja de Champmol se convertía en objeto de peregrinación y, por ende, de remisión de pecados en $1418^{15}$. Paralelamente, y vinculado a la devotio moderna con la que iniciábamos estas líneas, se potenció el culto a piezas de temática pasionista, de carácter monográfico o multisecuencial, que permitían a los devotos participar mentalmente en los sucesos pintados, realizar lo que V.J. Hulll denomina "peregrinación espiritual” capaz de ganar recompensas espirituales igual que la visita física a los Santos Lugares ${ }^{16}$.

\footnotetext{
${ }^{13}$ Se les rendían los mismos gestos de respeto que a las imágenes verdaderas -posición genuflexa del fiel, petición de milagros u ofrecimiento de promesas- pero ofrecían la particularidad de trasladar el culto público del templo al recóndito de los hogares y favorecer las prácticas devotas privadas. Algunas, inclusive, incorporaban frases cuyo recitado aseguraba beneficios espirituales para el devoto. Este y otros aspectos de los usos antropológicos de la imagen en H. BELTING, Imagen y culto. Una historia de la imagen anterior a la era del arte, Madrid, [1990] 2009.

${ }^{14}$ En el interior, se conservaba una tabla pintada y, en el exterior, una escultura. La concesión de perdones por León X incidió positivamente en la fama del santuario y en la llegada masiva de peregrinos. Según un testigo presencial, las copias no satisficieron las necesidades de los devotos y hubo llantos amargos por no conseguir las apreciadas imágenes. ¿De qué número de copias hablamos? En el segundo año de la peregrinación masiva, se documentan más de 100.000 reproducciones en arcilla y cerca de 10.000 en plata. Vid. D. FREEDBERG, El poder de las imágenes, Madrid, [1989] 2009, pp. 130-132 y R. SCHÖLCH, "La imagen y las imágenes. Alberto Durero y la controversia de las imágenes en la época de la Reforma", Durero y Cranach. Arte y Humanismo en la Alemania del Renacimiento, Madrid, 2007, p. 117.

15 J. NUECHTERLEIN, "Hans Memling's St Ursula shrine: the subject as object of pilgrimage", S. BLICK Y R. TEKIPPE (eds.), Art and Architecture of Late Medieval Pilgrimage in Northern Europe and the British Isles, Brill, Leiden, Boston, 2005, p. 53.

${ }^{16} \mathrm{El}$ autor alude a la capacidad desarrollada por el fiel de memorizar y visualizar de modo particular el vía crucis gracias a la contemplación de la obra de Hans Memling titulada Escenas de la Pasión de Cristo
} 


\section{La producción artística y sus modos}

Las razones sucintamente esbozadas explicitan el incremento cuantitativamente relevante de la producción artística en el período bajomedieval. Tal crecimiento fue posible por las dos formas de producción artística materializadas en el medievo: la obra por encargo realizada por artistas de reconocido prestigio -fundamentalmente, vía protocolos notariales- y la ejecución estandarizada. Mas cantidad, como veremos en las siguientes páginas, no siempre significó un mismo nivel de calidad.

\section{"Mercadurías artísticas"}

Desde tempranas fechas, fue convirtiéndose en una práctica habitual la compra de objetos en los santuarios de culto como recuerdo de la peregrinación o la visita realizada. Por conocido no es menos significativo el texto del Codex Calixtinus relativo a la venta de pequeños "souvenirs" -conchas principalmente- en torno a la catedral jacobea ${ }^{17}$. Algunos de estos objetos votivos fueron piezas sin valor o, por lo menos, no considerados por la historiografía artística durante un tiempo; otros, sin embargo, llegaron a adquirir una cierta calidad.

La venta propiamente dicha debía realizarse en tenderetes de fácil constitución o en sencillas tiendas, al modo de la que encontramos reproducida en una viñeta de las Cantigas de Santa María de Alfonso X. Nos referimos a la cantiga 9 (Códice Rico, ca. 1280-1284, Ms. T-I-1, Real Biblioteca de El Escorial, fol. 17r, viñeta 3) alusiva al encargo que una devota realizó a un monje en su peregrinación a Jerusalén: la adquisición de un recuerdo piadoso del viaje. Para ilustrarlo, el miniaturista situó al clérigo delante de una tienda de cuadros como traslación gráfica de la frase "del lugar donde vendían las imágenes". La viñeta tiene un claro carácter memorial al ser uno de los testimonios visuales más antiguos que avala el comercio estandarizado de objetos de $\operatorname{arte}^{18}$; además, independientemente de su carácter arquetípico, advertimos el uso de modos iconográficos caros a la estética gótica -un crucificado de tres clavos y una Virgen emotiva- y, en el caso de las imágenes marianas, la casi identidad de todos los modelos ${ }^{19}$. Las diferencias apenas afectan a la policromía. Este elemento se va a convertir en una cualidad de la producción estandarizada ya

(1470. Galería Sabauda, Turín). En dicha tabla, en formato de microescenas, se representa un completo ciclo cristológico pasionista que incluye desde la Entrada en Jerusalén al Noli me tangere (V.J. HULL, "Two Spiritual Pilgrimage in the Paintings of Hans Memling", S. BLICK y R. TEKIPRE, op. cit., 2005, p. 30).

17 Guía del peregrino a Santiago (Codex Calixtinus), M. BRAVO LOZANO (trad.), Sahagún, 1989, p. 72.

18 El más reciente acercamiento al arte de los talleres alfonsíes en el catálogo Alfonso X el Sabio, I.G. BANGO TORVISO (com.), Murcia, 2009.

19 Tal viñeta significa el conocimiento en la corte alfonsí de prototipos bizantinos. Vid. F. GUTIÉRREZ BAÑOS, "Pintura monumental en tiempos del Códice Rico de las Cantigas de Santa María", L. FERNÁNDEZ FERNÁNDEZ y J.C. RUIZ SOUZA (coords.), Cantigas de Santa María. Códice Rico, Ms. T-I-1. Real Biblioteca del Monasterio de san Lorenzo de El Escorial, Madrid, 2011, pp. 392-393. 
que la repetición de motivos agilizaba la ejecución de la obra e influía positivamente en el precio final de la misma ${ }^{20}$.

Esta forma de producción artística, destinada a satisfacer una amplia demanda de productos artísticos a un precio razonable, adquirió unas espectaculares dimensiones al final de la Edad Media ${ }^{21}$. La riqueza económica y el comercio fueron los dos vectores en torno a los que se incardinó tal "trasiego" de obras de arte que, en el período referido, tuvo dos focos de atención preferentes: los alabastros ingleses y el mercado flamenco ${ }^{22}$. La fabricación de obras para un comprador a priori anónimo conforma que éstas no planteen ni innovaciones tipológicas ni temáticas; al contrario, una de las razones de su éxito radicó en su acomodación a unos criterios generales de gusto de la época ${ }^{23}$.

\section{Alabastros ingleses}

Las abundantes canteras de alabastro existentes en Nottingham y Londres incidieron positivamente en la proliferación de unos talleres artísticos dedicados a elaborar productos de forma masiva que, en buena medida, se destinaron a la exportación ${ }^{24}$.

20 La obra alfonsí, asimismo, alude a otros aspectos de la producción artística seriada: el empleo de moldes. La cantiga 196 refiere la conversión de un gentil tras un milagro de la Virgen por el que, en plantillas hechas para fabricar ídolos, se obtenían imágenes marianas: "E porend' aqueste/ que vos dixi da primeira,/ sacerdote dos gentiis,/ queria de gran maneira/ componer huna omagen / d'idolo, que de certeira/ cousa lle désse desposta/ faland' e non fosse muda./ Senpre punnou muit' a Virgen/ per u fosse connoçuda..." (Alfonso X el Sabio, cantiga 196, W. METTMANN (ed.), Cantigas de Santa María, II, Madrid, 1986, pp. 234).

21 Aunque el tema dista mucho de estar agotado, recientes novedades bibliográficas están profundizando sobre este modo de producción artística desarrollado en el medievo: M. TOMASI (dir.), S. UTZ, L'art multiplié. Production de masse en série, pour le marché dans les arts entre Moyen Âge et Renaissance, Viella, 2011.

22 Este modo de producción artística, de hondas reflexiones sociológicas, tuvo otros focos creadores como los talleres de marfil de los Embriachi, por no significar un número heterogéneo de cenobios y centros devocionales. Recientes trabajos han ahondado en esta dirección como el de KATJA BOERTJES relativo a la actividad comercial configurada a partir de la veneración a una sagrada lágrima de Cristo en la localidad de Vendôme. La autora profundiza en la celebración de los mercados de los viernes -especialmente los dedicados a San Lázaro- con la venta cuantitativamente notable de colgantes, medallas, insignias y especialmente ampollas que repetían el tema de dos figuras flanqueando la venerada reliquia. Tales objetos tenían una función apotropaica, específicamente contra la enfermedad de la vista (K. Boertjes, "Pilgrim Ampullae from Vendôme: Souvenirs from a Pilgrimage to the Holy Tear of Christ", S. BLICK y R. TEKIPRE, op. cit., 2005, pp. 443-472).

${ }^{23}$ Una aproximación global al tema, tanto desde la mirada del comprador como del mercader, así como a la arqueología del acto de comprar con el análisis tipológico de tiendas y almacenes con sus adornos y accesorios, las horas de mercado o sus tiempos específicos en el sugerente texto de E. WELCH, De compras en el Renacimiento, Valencia, [2005] 2009.

${ }^{24}$ La importancia del centro de Nottingham determina que genéricamente esta producción seriada se llame Notthingham alabasters. Sus talleres extendieron su producción entre 1340 y 1540 , siendo posteriores los de Londres. Estos artesanos eran conocidos con varios nombres, entre otros con el significativo de imagemakers. Vid. F. CHEETMAN, English medieval alabasters. With a catalogue of the collection in the Victoria and Albert Museum, Oxford, 1984; y P. WILLIANSON, Object of Devotion: Medieval English Alabaster Sculpture from the Victoria and Albert Museum, London, 2010. 
"Cajas repletas de alabastros", según indican los documentos ${ }^{25}$, llegaron en los barcos ingleses a distintas partes de Europa ${ }^{26}$ y distribuyeron por todo el continente esta mercancía artística ${ }^{27}$.

El alabastro es un material fácil de trabajar que, además, tiene una buena apariencia y es relativamente barato. Estas cualidades lo convirtieron en un material óptimo para una producción quasi industrial ${ }^{28}$. Dominan las figuras de canon corto, ojos abultados y una escasa atención hacia el detalle o el tratamiento espacial. Finalmente, un color impactante y llamativo servía para tapar los posibles defectos y mejorar el resultado final.

Su producción se decantó, fundamentalmente, hacia piezas de carácter doméstico afines en su temática a asentadas devociones tardogóticas. Es el caso de las cabezas cortadas de San Juan Bautista ${ }^{29}$-habituales en los hogares ingleses y sedes gremiales por su condición apotropaica ${ }^{30}$, de las imágenes de San Cristóbal -patrono de

25 Apreciamos el alcance de esta producción seriada en el juicio celebrado en 1491 entre el escultor Nicolas Hill y su marchante por la demora en el pago de 58 cabezas de Juan Bautista (Cit. N. RAMSAY, "La production et exportation des alabâtres anglais medievaux", X. BARRAL I ALTET (ed.), Artistes, artisans et production artistique au Moyen Age. III. Fabrication et consummation de l'oeuvre, París, 1990, p. 1753). Tampoco el caso fue un unicum en la época, como constata el libro de F. CHEETMAN, op. cit., 1984, p. 317.

26 El comercio de Castilla con Inglaterra utilizó como medio de conexión los puertos del Cantábrico desde donde la mercancía alabastrina, barata y de resultados estéticos notables, se extendía vía terrestre o marítima a lugares alejados de los principales centros de producción artística. Para completar Vid. los trabajos de J. YARZA LUACES ("Alabastros esculpidos y comercio Inglaterra-Corona de Castilla en la Baja Edad Media", Homenaje al profesor Hernández Perera, Madrid, 1992, pp. 605-617; y "Baja Edad Media”, M. BENDALA (dir.), Manual de Arte Español, Madrid, 2003, p. 311); J. MARTÍNEZ DE AGUIRRE ("Mercaderes y arte gótico en las villas marineras del reino de Castilla", Santander y Cantabria en la Conquista de Sevilla. 750 Aniversario, Santander, 1999, pp. 79-110); y A. FRANCO MATA (El retablo gótico de Cartagena y los alabastros ingleses en España, Murcia, 1999). No obstante, por la frecuencia con la que estas transacciones se vieron afectadas por la piratería, ciertas piezas terminaron como regalos piadosos en las iglesias próximas a la costa. Menciona varios ejemplos B. CAUNEDO DEL POTRO, La actividad de los mercaderes ingleses en Castilla (1475-1492), Madrid, 1984.

27 La movilidad de las piezas alabastrinas medievales continuó con posterioridad al Medievo. La promulgación de la orden de Disolución de los Monasterios de 1530 o el acta de Supresión de los libros e imágenes de 1549 propiciaron el exilio forzado de territorio inglés de un buen número de estos objetos.

${ }_{28}$ Los talleres son diversos e imponen sus elementos distintivos; aunque por encima de éstos se aprecian ciertas pautas comunes a nivel iconográfico, compositivo y estético. Analiza esas particularidades estilísticas S. MORALEJO, "Retablo de la vida de Santiago ofrecido por John Goodyear", Santiago, camino de Europa. Culto y cultura en la peregrinación a Compostela, Santiago de Compostela, 1993, pp. 506-507.

29 La difusión de la devoción al Predecesor queda acreditada en las piezas de esta temática conservadas en diferentes museos europeos. Pormenorizados trabajos se han acercado a estos ejemplares: J. HERNÁNDEZ PERERA, "Alabastros ingleses en España”, Goya, 22 (1958), pp. 216-222; y "Más relieves góticos de alabastro en España”, Homenaje a Elias Serra Rafols, La Laguna, 1970, pp. 251-264; L. RODRÍGUEZ PEINADO, "Dos alabastros inéditos en el Museo Nacional de Artes Decorativas de Madrid", Boletín del Museo Camón Aznar, XXXIV (1988), pp. 135-142; L. LAHOZ, "Un alabastro inglés de Lermanda", Boletín del Seminario de Arte y Arqueología, LV (1989)]; o M.C. MUÑOZ PÁRRAGA, "Precisiones iconográficas sobre un alabastro inglés de la catedral de Sigüenza (Guadalajara)", Anales de Historia del Arte, 4 (1994), pp. 805-813.

30 Para atender a esta función, algunas tallas tienen una amplia oquedad posterior convertida en puntual receptáculo de reliquias o, de forma más habitual, de objetos que adquirían poderes curativos, específica- 
los caminantes o de la muerte súbita ${ }^{31}$ o de la Trinidad, de gran predicamento en el Medievo ${ }^{32}$ (fig. 3). Incidiendo en la ejecución material de estas piezas, conviene remarcar la fidelidad a un mismo prototipo que, independientemente del marco temporal de ejecución, solía incluir pocas variantes.

Dónde se colocaban y cómo se veneraban estas obras alabastrinas son preguntas que aún requieren estudios pormenorizados, aunque tenemos una cierta información al respecto. Sabemos de su acomodo directo sobre determinadas piezas del mobiliario doméstico - la armadura externa de la chimenea podía actuar de peana- o de su inclusión en mazonerías de madera (Anunciación y la Trinidad, c. 1400. Victoria \& Albert Museum. A 193-1946) y, en el caso de las cabezas del Predecesor, de su disposición sobre platos de madera, alabastro e inclusive plata. A este respecto, se ha observado que los inventarios domésticos donde se mencionan estas piezas también suelen incluir unos aderezos textiles llamados "el vestido de San Juan" empleados, probablemente, para tapar las tallas

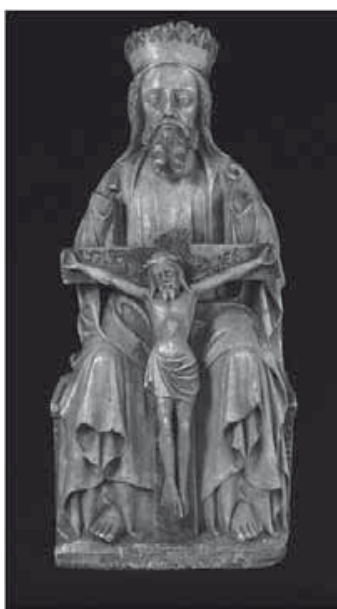

Fig. 3. Anónimo, Trinidad, ca. 1400 (Victoria \& Albert Museum, Londres. A531946). cuando no eran usadas y, por consiguiente, ocultar temporalmente su visión ${ }^{33}$.

Un similar planteamiento afectó a los retablos alabastrinos, destinados mayoritariamente para el ornato de altares templarios. En ellos, además de las características ya mencionadas, compete hablar de seriación de secuencias y, en éstas, de una similar representación compositiva. Pocos se han conservado en estado completo con su mazonería como el retablo de los Gozos de María, popularmente conocido como el retablo Swansea (c. 1480. Victoria \& Albert Museum, A89-1919). Otros muchos han sobrevivido en estado fragmentario. Así ocurre con el procedente de la localidad abulense de Collado de Contreras (Museo Diocesano de Ávila) ${ }^{34}$; aun-

mente contra el dolor de cabeza. Algunas de estas testas aparecen acompañadas por el Agnus Dei, las imágenes de Cristo varón de Dolores, la Piedad u otras figuras hagiográficas y angélicas. Nuevamente, el Victoria \& Albert tiene una notable colección, entre las que destacamos varias piezas del siglo XV (A79-1946. A127E1946. A127A-1946). Su análisis en F. CHEETMAN, op. cit., 1984.

31 La talla de San Cristóbal del Victoria \& Albert Museum (A18-1921 y A2-1912) nos sirve como ejemplo; a la par que acredita el valor memorial de la tabla ya mencionada de Santa Bárbara por el similar ornato hagiográfico de su chimenea. Apreciemos, pues, como la elección de Robert Campin distó mucho de ser azarosa (fig. 1).

32 El Victoria \& Albert conserva varios ejemplos adscritos a este prototipo con variantes de tono secundario: A53-1946. c.1400; 10-1882. siglo XV; A88-1946. siglo XVI. Más datos en F. CHEETMAN, op. cit., 1984, pp. 297-299.

33 F. CHEETMAN, op. cit., 1984, p. 28.

34 Los investigadores otorgan a la pieza, hoy desmenuzada, una cronología comprendida entre 1420 y 1460. Vid. J. YARZA LUACES, "Un tríptico inglés de alabastro en Collado de Contreras (Ávila)", Archivo Español de Arte, XLI (1968), 131-139; y J. ARA GIL, "Escultura”, Historia del Arte en Castilla y León. III. Gótico, Valladolid, 1995, p. 292. 
que, por las particularidades antes mencionadas, tomando como modelo el retablo inglés es posible encajar las tablas del Nacimiento, la Adoración de los Magos y la Trinidad y reconstruir su diseminada fisonomía ${ }^{35}$.

\section{Mercado flamenco}

Los alabastros ingleses no alcanzaron la calidad ni la entidad de las obras flamencas. La demanda de arte flamenco fue generalizada en toda Europa ${ }^{36}$. De este

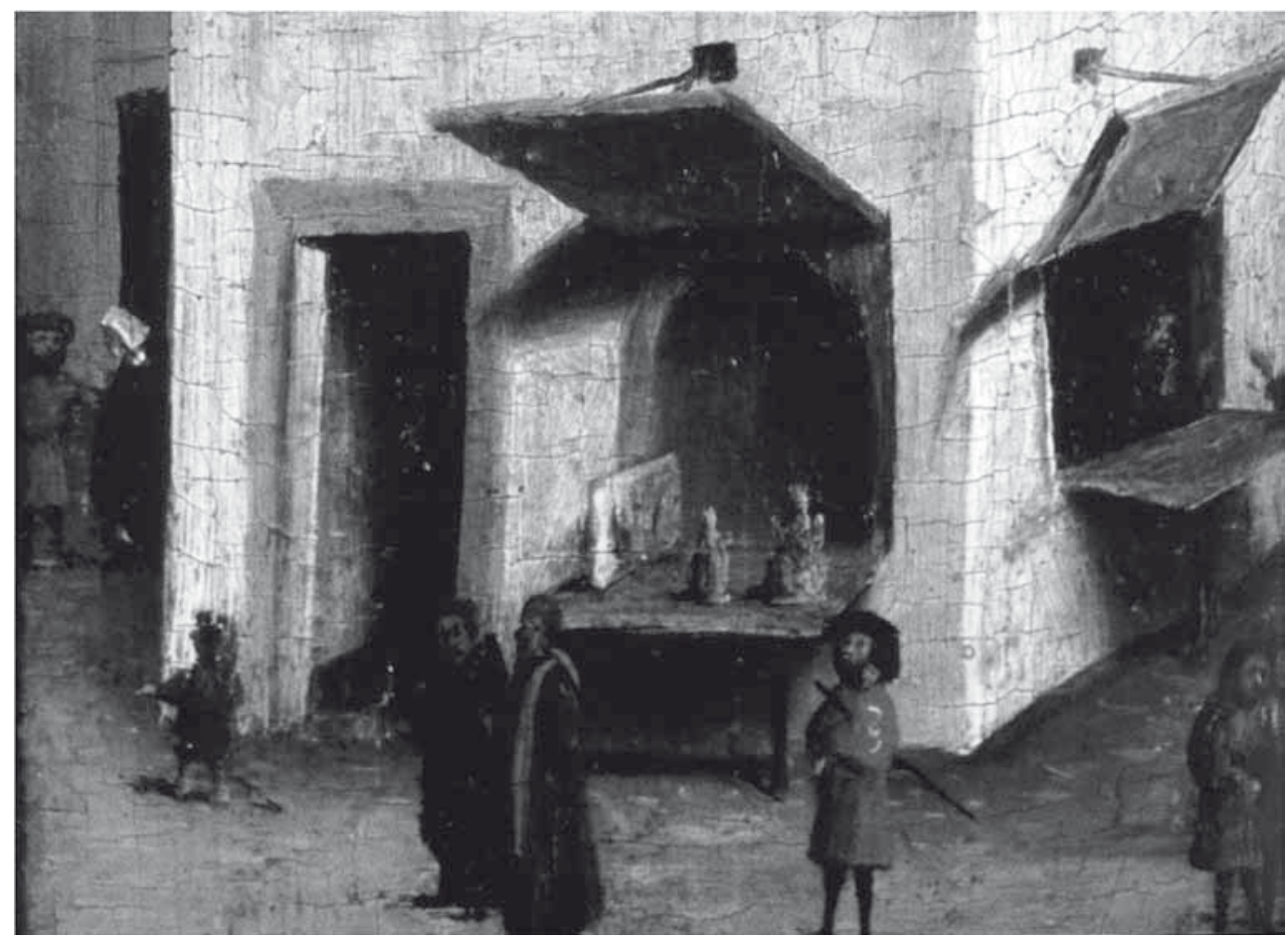

Fig. 4. Conrad Witz, Santa Catalina y Santa María Magdalena, ca. 1440, detalle de la vivienda-tienda de productos artísticos (Museè de Bèaux Arts, Strasbourg).

35 A esta producción seriada, y por tanto de dificultosa datación, hay que sumar los encargos concretos que, cuantitativamente menos numerosos, obedecieron a una petición expresa del comitente y, por tanto, frecuentan una iconografía más particular. La catedral de Santiago de Compostela conserva el retablo que el clérigo John Goodyear donó al templo antes de 1456. Vid. S. MORALEJO, op. cit., 1993, pp. 506-507.

36 Antes de seguir, conviene precisar el alcance otorgado al término flamenco, usado comúnmente y que adolece de cierta inexactitud, ya que Flandes fue una zona muy activa de los Países Bajos, pero también existieron otros centros notables que, en buena medida, capitalizaron la producción artística. En palabras de Javier MARTÍNEZ DE AGUIRRE, este criterio geográfico restrictivo puede verse compensado por el que durante los siglos XIV a XVII se tuvo en Castilla: los Países Bajos en su conjunto eran llamados Flandes ("Notas sobre la importación de obras escultóricas en la Castilla bajomedieval", Actas del Congreso Internacional sobre Gil Siloe y la Escultura de su época, Burgos, 2001, pp. 367-380). 
ámbito, emigraron artistas y a él acudieron otros foráneos para aprender; además, surgieron numerosos talleres dedicados a una especie de producción "pre-industrial" y a la fabricación de obras para la exportación ${ }^{37}$.

Una de las primeras cuestiones que cabe analizar es la relacionada con los lugares de venta de esta mercaduría. Visualizamos la respuesta en la pintura Santa Catalina y santa María Magdalena (c. 1440. Museé de Bèaux Arts, Strasbourg) de Conrad Witz. La secuencia, relativa a una sagrada conversación entre las dos santas, acontece en un templo; mas la puerta abierta del mismo nos sitúa ante una calle comercial y, en concreto, ante lo que podemos valorar como la vivienda de un artífice. La planta alta tenía un uso privado y doméstico. La intermedia, muy iluminada y aireada, solía usarse como taller. Y la baja se destinaba a expositor y lugar de venta de la mercancía, tal y como rememora la tabla (fig. 4$)^{38}$.

A estos espacios, hemos de incorporar los mercados semanales de un día de duración y, de forma preferente, las ferias ya que durante su celebración, según establecían las guildas, sólo se podían realizar transacciones comerciales en ellas ${ }^{39}$. Precisamente, conservamos un testimonio excepcional, en clave de contemporaneidad, sobre estos acontecimientos: el relato de Andanzas e viajes de un hidalgo español (1435-1439) de Pero Tafur. El viajero castellano al evocar su visita a Centroeuropa dedicó varias páginas a la expendeduría flamenca significando la intensidad de la protagonizada por la ciudad de Brujas $^{40}$, la especialización textil conseguida por la villa de $\operatorname{Ras}^{41}$ y el carácter e importancia de la feria de Amberes. De forma particular, Tafur alude a la organización temática de esta última y al empleo de espacios religiosos como referencia ubicativa o lugar de venta ${ }^{42}$. Conforme a su

37 La economía de los Países Bajos - activa en los sectores naval, metalúrgico y de productos de lujotuvo su principal armazón en la industria textil. Allí donde llegó esta industria se observa la presencia de mercaduría artística. Vid. E. STOLS y W. THOMÁS, "Flandes y las islas Canarias en la primera apertura del mundo 1450-1550”, F. GALANTE (dir.), Lumen Canariense: el Cristo de La Laguna y su tiempo, San Cristóbal de la Laguna, 2003, pp. 38-39.

38 El uso "fotográfico" de esta imagen ha sido señalado por S. NASH en uno de los textos más atractivos y sugerentes sobre el arte del período: Northern Renaissance art, Oxford, 2009.

39 Un acercamiento a estos aspectos en F. VERMEYLEN, Painting for the market. Commercialization of art in Antwerp's Golden Age, Turnhout, 2003, pp. 132 y 22.

40 "Esta çibdad de Brujas es una grant çibdat muy rica é la mayor mercaduría que ay en el mundo, ... Aquí se despachan mercadurías de Inglaterra, Alemaña, Bravante, Olanda, Stlanda, Borgoña, Picardia... E de aquí se tiran todas las mercadurías que van por el mundo, e paños de lana, e paños de Ras, e toda tapecería e otras muchas cosas nescessarias a los onbres" (PERO TAFUR, Andanças e viajes de un hidalgo español (1436-1439), M. JIMÉNEZ DE LA ESPADA (ed.), Barcelona, 1982, p. 254).

41 "E fuí en Picardía á una çibdat que se llama Ras, que es del duque de Borgoña; es muy gentil çibdat, é muy rica, mayormente destos paños de paredes é toda tapeçería; é puesto que ya en otras partes los labran, pero, con todo eso, bien se paresçe la ventaja de lo que se faze en Ras...” (PERO TAFUR, op. cit., 1982, p. 254).

42 "E fuí á la çibdat de Anvéres, que es en Bravante, señorío del duque de Borgoña... Esta es, la feria que aquí se faze, la mejor que en el mundo todo ay, e sin dubda, quien quisiese ver el mundo junto o la mayor parte del en un lugar ayuntado, aquí se podría ver. El señor duque de Borgoña sempre venie a esta feria... allí fallé los burgaleses, que en Brujas están de continuo. Aquí es la más fermosa cosa de ver del mundo, e la mayor riqueça, e el mayor enjoyamiento, e la orden que se tiene en las mercadurías; en un monesterio de Sant 
testimonio, sabemos que en el monasterio de San Francisco se vendía la pintura, en el de San Juan la tapicería y en el de Santo Domingo la orfebrería.

Para entender la importancia de estos acontecimientos comerciales hay que insistir en su duración prolongada -cada feria podía prolongarse hasta seis semanas-, motivo por el que se convirtieron en óptimos lugares para la exposición y venta de productos, a la par que en idóneos observatorios de tendencias ${ }^{43}$. Famosas fueron las de Brujas, Frankfurt, Lyon o Amberes ${ }^{44}$. Esta última ciudad desarrolló sus mercados en torno a Semana Santa, a mediados de mayo, y la fiesta de San Bavón, a finales de agosto.

La regularidad e importancia de este negocio favoreció el uso de unos lugares específicos que facilitaran el mismo ${ }^{45}$, los llamados pand $^{46}$. Volviendo al caso de Amberes, la guilda de los joyeros y de los pintores organizó el pand de los dominicos ${ }^{47}$ en las propias estructuras claustrales mediante el arrendamiento por comerciantes y artistas de parte del espacio religioso ${ }^{48}$. A éste, le sucedió el llamado pand de Nuestra Señora que, durante casi un siglo, ejerció prácticamente el monopolio de la venta de cuadros, pinturas y grabados. En este caso, corresponde hablar de una construcción de nueva planta edificada de forma expresa para la venta de objetos artísticos; aunque recabemos que su disposición y planimetría de galerías

Françisco se vende todo lo de pintura, e en una yglesia de San Juan todos los paños de Ras, e en un monesterio de Sant Domingo toda la orfebrería de oro, en ansí repartidos por los monesterios e yglesia e después por las calles todas las otras cosas, e fuera de la çibdat, a la una puerta, está una calle muy larga, de la una parte esta una gran cavalleriza, e de la otra e ansí grandes aposentamientos..." (PERO TAFUR, op. cit., 1982, p. 254).

43 J.C. WILSON, "Marketing paintings in late medieval Flanders and Brabant", X. BARRAL I ALTET (ed.), op. cit., 1990, pp. 621-628.

44 La feria de Brujas fue una de las más importantes teniendo su propia reglamentación. Conocemos detalladamente las regulaciones fijadas por la cofradía de escultores a través del trabajo de M. MARTENS, "Some aspects of the origins of the Art Market in 15th-Century Bruges", M. NORTH y D. ORMROD (org.), C.E. NÚÑNEZ (ed.), Markets for art, 1400-1800, Sevilla, 1998, pp. 29-40.

45 En otros lugares donde se desarrolló un comercio a gran escala se articularon medidas parecidas pero no de esa entidad arquitectónica. En Venecia, fue famosa la feria celebrada con motivo de la Ascensión, la Sensa, donde los comerciantes cerraban sus tiendas y se instalaban en casetas de madera de una endeleble prestancia ubicadas en la Plaza de San Marcos. La mercancía a vender era diversa desde obras de artistas no venecianos hasta pinturas de la Virgen incluyendo, según datamos en un caso abierto ante la Inquisición en 1585, "pinturas obscenas” (M. BURY, The Print in Italy. 1550-1620, London, 2001, p. 177). También la Sensa ejercía de observatorio de tendencias puesto que los artesanos de cristal usaban este evento para introducir nuevas modas y estilos (E. WELCH, op. cit., [2005] 2009, pp. 179-181).

${ }^{46}$ El análisis de estos aspectos en F. VERMEYLEN, op. cit., 2003, p. 132.

${ }^{47}$ La guilda de los pintores de Bruselas también se incorporó a este pand mencionado por Tafur. Vid. V. GINSBOURGH y C.D. THORSBY, Handbooks of the economics of art and culture, Oxford, 2006 , p. 87.

48 Los dominicos confiaban a una especie de consorcio -conformado por miembros de la guilda de San Lucas y San Nicolás- el control de los alquileres derivados de estas prácticas comerciales que, según VERMEYLEN, acontecían en la esquina suroeste del claustro. En 1479, como signo de crecimiento del pand, se construyeron nuevas salas de venta fuera del convento (op. cit., 2003, pp. 20 y ss). La circunstancia no fue excepcional; aproximadamente desde 1482, en Brujas se celebraba un mercado anual de pinturas en torno al convento de San Francisco (J. YARZA LUACES, "Comercio artístico Flandes-reinos hispánicos", La pintura gótica hispanoflamenca. Bartolomé Bermejo y su época, Barcelona, 2003b, p. 107). 
porticadas en torno a un patio central mantiene el recuerdo de las estructuras claustrales $^{49}$. Finalmente, y ya inmersos en el siglo XVI, compete mencionar la llamada "galería de pintores" -schilderspand-emplazada en el piso superior de la nueva bolsa de Amberes, el centro financiero de la ciudad. La particularidad de sus casi 100 tiendas era que permanecían abiertas todo el año, no sólo en tiempo feriado, y podían ampliamente satisfacer las necesidades de una clientela variada ${ }^{50}$.

Esta infraestructura mercantil permitió la provisión de un amplio stockaje de obras de arte destinadas al abastecimiento interno y, especialmente, a la exportación masiva de productos a los distintos países de Europa. Resta, pues, aludir a las vías de difusión de este comercio artístico ${ }^{51}$.

La exportación mayoritaria se realizó a través de las rutas normales de transacción. Los marchantes solían depositar los productos en ferias locales, en una secuencia parecida a la que exhibe el cuadro flamenco de David Vinckbooms titulado La Feria (1608. Braunschweig, Herzog-Anton-Ulrich Museum) donde la mercancía artística coexiste con otra de carácter heteróclito. La de Medina del Campo fue la más notable en el reino de Castilla ${ }^{52}$. A este respecto, sabemos que la reina Isabel la Católica adquirió tapices en este recinto o que la estatua de la Virgen del Retablo de los Ángeles del marqués de Santillana tuvo esta procedencia ${ }^{53}$.

Otra vía de intercambio fue la promovida por comerciantes de diferente nacionalidad que, animados por la favorable coyuntura económica, establecieron su residencia en Centroeuropa. Fue común que éstos, al regresar a sus ciudades natales, incorporasen a su equipaje los bienes artísticos atesorados. En el reino de Castilla,

49 Los miembros del gremio de San Lucas, a los que en 1481 se asoció la corporación de pintores de Bruselas, cimentaron el nuevo edificio cerca de la iglesia de Nuestra Señora -razón del nombre del pand- que posteriormente adquirió el estatus de catedral (F. VERMEYLEN, op. cit., 2003).

50 Actuaban a modo de las galerías de arte actuales con puestos de mercancía más o menos selecta, no descartándose los pedidos particulares.

51 Los trabajos de M.J. GÓMEZ BARCENA han profundizado sobre las consecuencias de este quehacer artístico en la Corona de Castilla, especialmente, Retablos flamencos en España, Madrid, 1992; y "Arte y devoción en las obras importadas. Los retablos "flamencos" esculpidos tardogóticos: estado de la cuestión", Anales de Historia del Arte, 14 (2004), pp. 33-71. A ellos hay que sumar los textos de J. YARZA LUACES, op. cit., 2003b, pp. 107-115 y las aportaciones insertas en el misceláneo trabajo C. COSMEN, V. HERRÁEZ Y M. PELLÓN (coords.), El intercambio artístico entre los reinos hispanos y las cortes europeas en la Baja Edad Media, León, 2005.

52 Durante el reinado de los Reyes Católicos, la feria de Medina alcanzó su mayor índice de desarrollo debido a su conexión directa con las ferias de Brabante y Lyon y al empleo, como estadios intermedios, de los puertos de Santander, Castro Urdiales o Laredo. Esta red comercial permitió la llegada masiva de las llamadas "cosas de Flandes" (J.I. HERNANDO REDONDO, "El comercio del arte en las ferias de Medina del Campo durante el reinado de los RR.CC.", Comercio, mercado y economía, 2004, p. 95). Sobre el desarrollo de esta feria castellana M.A. LADERO QUESADA, Las ferias de Castilla, siglos XII al XV, Madrid, 1994.

53 El encargo corresponde a Iñigo López de Mendoza, primer marqués de Santillana, militar y sobre todo gran humanista, poseedor de una gran biblioteca y célebre poeta. Su datación aproximada deriva de un codicilo redactado por el marqués en 1455 donde habla de forma expresa del retablo del Hospital de Buitrago aludiendo a la talla mariana que "mandé traer de la feria de Medina". Cit. M.A. ZALAMA, "Retablo de los Ángeles", Reyes y Mecenas. Reyes Católicos, Maximiliano I y los inicios de la Casa de los Austrias, Toledo, 1992, p. 308. 
destacaron especialmente los burgaleses. Es el caso del mercante García de Salamanca a quien corresponde el encargo en los talleres de Amberes de un retablo funerario para la iglesia de San Lesmes de la población castellana ${ }^{54}$.

Finalmente, no podemos olvidar la existencia de comerciantes flamencos afincados en otros ámbitos. Un importante número de los mismos instaló su morada en Madeira y las islas Canarias atraídos por la producción y el cultivo del azúcar ${ }^{55}$. En los mismos barcos empleados para sus transacciones crematísticas, llegaron a territorio insular un buen número de obras centroeuropeas que hoy forman parte del patrimonio artístico canario, como el Cristo de la Laguna $^{56}$ o la talla de Santa Ana, la Virgen y el Niño (ca. 1510-1520, Amberes) ${ }^{57}$ (fig. 5).

Las similitudes de esta última imagen con otras piezas de igual temática conservadas en lugares dispares nos permite apreciar el concepto de seriación mantenido por estos talleres ${ }^{58}$. Seriación conseguida por procedimientos tales como la separación de tareas en un taller, el empleo de copias o dibujos y, según el material empleado, la utilización de moldes o la prefabricación de ciertas partes ${ }^{59}$.

Estos modos de producción quasi industrial respondieron satisfactoriamente al nivel cuantitativo de la producción artística ${ }^{60}$. Para mantener el nivel cualitativo, las guildas o corporaciones establecieron una serie de garantías o controles de

${ }^{54}$ La personalidad y comitencia de este adinerado burgalés en M.J. GÓMEZ BARCENA, "Escultura gótica de importación en Burgos. El retablo de la Santa Cruz en la iglesia de san Lesmes", Boletín del Instituto Fernán González, 209 (1994/2), pp. 288-296.

55 Tras la conquista de las Islas Canarias por los Reyes Católicos, se estableció el cultivo de la caña de azúcar en la isla de la Palma. El hecho propició el desarrollo de un fructífero comercio ya que el exótico producto procedente de Oriente había pasado de ser una puntual píldora farmacéutica hasta convertirse en el postre festivo de pasteleros y la golosina preferida de los niños. Mayor información en J.G. EVERAERT, "Flandes y la Palma, el reclamo del azúcar", B.J. GARCÍA GARCÍA (coord.), El fruto de la fe. El legado artístico de Flandes en la isla de la Palma, Madrid, 2005, p. 43.

56 La talla, realizada en 1514 por el artista Louis van der Vule, fue trasladada a la Laguna gracias al interés de Juan Benítez -el conquistador de la Palma y Tenerife- y del adelantado Alonso Fernández de Lugo. Dicha imagen recibió un estudio exhaustivo por F.J. GALANTE, "Canarias, el Cristo de la Laguna y sus relaciones con la escultura gótica tardía”, Lumen canariense, I, pp. 215-260.

57 La escultura, muy afín a la devoción tardogótica, formó inicialmente parte de la colección de Jacques Groenemberg -Jacome de Monteverde en su versión castellana- oriundo de Colonia y afincado en la isla de la Palma para administrar sus plantaciones de cañaverales (R. DIDIER, "A propósito de la escultura en los antiguos Países Bajos al final de la Edad Media", Lumen Canariense, I, p. 106; y C. NEGRIN, "Santa Ana, la Virgen y el Niño", B.J. GARCÍA GARCÍA (coord.), op. cit., 2005, pp. 209-212).

58 Los mismos planteamientos estilísticos-comerciales cabe aplicar a la producción de retablos donde, igual que mencionábamos en la obra alabastrina, es factible hablar de seriación temática.

${ }^{59}$ L.F. JACOBS profundiza en alguno de estos aspectos, a la par que diserta sobre el diferente carácter aplicable a la palabra copia: mímesis, variatio o reproducción de una figura y un elemento compositivo a modo de cita (Early Netherlandish carved altarpieces, 1380-1550. Medieval Tastes and Mass Marketing, Cambridge, 1998, pp. 209-234).

${ }^{60}$ El estudio de estos talleres ha requerido diversos estudios y congresos como el organizado por el Louvre en 2001: S. GUILLOT DE SUDUIRAUT (coord.), Retables brabançons des XVe et XVIe siècles, París, 2002. Una de las ponencias apunta el uso de la dendrocronología para la más precisa datación de estas piezas. 


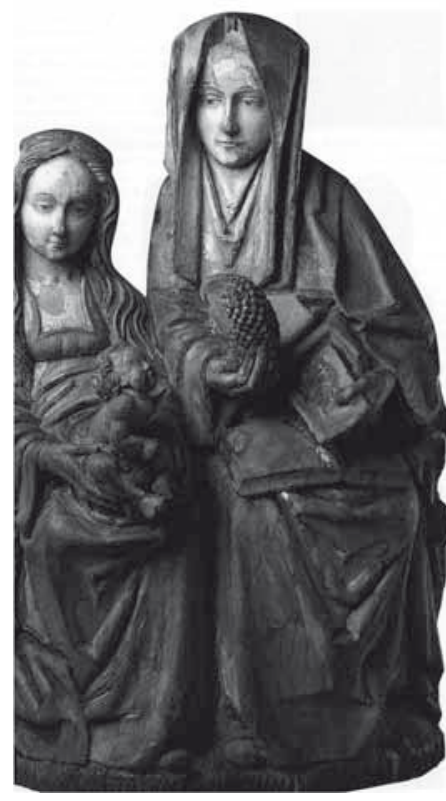

Fig. 5. Anónimo, Santa Ana, la Virgen y el Niño, ca. 1510-1520 (Santa Cruz de la Palma, Amberes, Col. Particular).

calidad. Son los poinçons, marcas pirograbadas en lugares poco visibles que aseguraban el nivel de los materiales empleados -especialmente de la madera y de la policromía- y al comprador que la pieza tenía el valor que pagaba por ella ${ }^{61}$. Cada ciudad tuvo sus propias marcas. Amberes empleó el castillo coronado por dos manos, la mano/manos y las armas de la ciudad o la palabra Antverp, respectivamente, para garantizar la calidad de la caja de carpintería, la madera de roble y la pintura. Bruselas avaló la mazonería con el compás y la garlopa, la madera con el martillo o mazo y la lámina de oro y demás material pictórico con el vocablo Bruesel, a veces abreviado con una B. Por su parte, la ciudad de Malinas acuñó las armas de la ciudad -4 bandas paralelas y verticales- como garante de la calidad de la madera y la locución Mechlen, ocasionalmente el monograma M, para la policromía ${ }^{62}$.

Los poinçons, por tanto, constituyen una especie de denominación de origen de las piezas al identificar la zona de realización del producto y, en la actualidad, una interesante herramienta para el historiador del arte. De tal modo, si volvemos a la citada imagen de Santa Ana, la Virgen y el Niño, la mano pirograbada en su peana acredita su realización en Amberes ${ }^{63}$ (fig. 5).

Santa Ana participa del universo devocional del final de la Edad Media, igual que los llamados Cristos de la paciencia o Cristos sentados en la roca fría plenamente entreverados en los principios de la devotio moderna. Son Cristos lacerados,

${ }^{61}$ Conviene insistir que estas marcas afectaban básicamente a la obra en madera y que prescribían el empleo de madera de roble o de nogal bien seca (R. DIDIER, "Reflexiones sobre la escultura de los antiguos países Bajos meridionales a principios del siglo XVI”, B.J. GARCÍA GARCÍA (coord.), op. cit., 2005, p. 143). A estas marcas, se podían añadir otras personales y raramente firmas o monogramas. La realidad, no obstante, podía ser mucho más compleja ya que una obra pudo empezarse en una ciudad y terminarse en otra y, en ese caso, llevar las marcas de las dos localidades. También hay que significar que algunos pedidos escapan a esta reglamentación, las esculturas importantes pueden no tener marchamo y, a veces, éstos van acompañados de otras señales - ¿talleres?, ¿autores?- cuyo significado no se ha dilucidado todavía. Una reflexión sobre esta complejidad en Lumen canariense, I, pp. 89 y ss.

${ }^{62}$ El reglamento de la guilda de Amberes data del 9 de noviembre de 1470 y se renovó el 20 de marzo de 1493. El de Bruselas corresponde al 10 de mayo de 1455. En cuanto a la ciudad de Malinas, sólo podemos precisar que a principios del siglo XVI ya estaba vigente (Lumen canariense, I, p. 89).

${ }_{63}$ También advertimos el vaciado por su parte posterior para aligerar su peso y evitar su resquebrajamiento por los problemas de dilatación o contracción de la madera. 
sufrientes y solitarios que, en ocasiones, llevan postizos y se produjeron de forma estandarizada. Entre los numerosos ejemplos conservados, sobresale el ejemplar custodiado en la capilla de San Enrique de la catedral de Burgos (ca. 1500) cuyos poinçons -manos pirograbadas en la basa- atestiguan su cincelado en los talleres de Amberes ${ }^{64}$.

La ciudad de Malinas convirtió casi en una especialidad la producción de Niños Jesús que tuvieron un gran éxito ${ }^{65}$. Eran pequeñas esculturas de madera, policromadas y en parte doradas, con un similar prototipo anatómico que no resultaba visible ya que tenían un guardarropa completo y todo tipo de accesorios como coronas, collares, anillos y amuletos. Tradicionalmente poco estimados por la historiografía artística, hoy reciben una nueva mirada en los novedosos estudios de género en su condición de regalo frecuente entregado a las novicias al ingresar en el convento. Además, convendría no olvidar que en las celebraciones navideñas fueron objeto de una especial veneración ${ }^{66}$. Lo apreciamos en los ejemplos depositados en diferentes colecciones privadas, el Museo de Arte e Historia de Bruselas (Niño Jesús. c. 1500) o el de las Ferias de Medina del Campo (Niño Jesús. c. 1500) ${ }^{67}$.

Cerramos este capítulo, mencionando un último aspecto sobre el que tenemos poca información: los procedimientos empleados en el transporte de las piezas. Las fuentes de análisis, procedentes de inventarios y documentos de la época, aluden a cajas y arcones donde frecuentemente iba amontonada la mercancía al modo de cómo se representa en la pintura de François Bunel II, A dealer's shop (ca. 1590, Mauriishuis, The Hague $)^{68}$. No obstante, debió ser inevitable la existencia de contratiempos -desde robos a hundimientos pasando por otro tipo de deterioros- que impidieran la llegada de la carga a su lugar de destino ${ }^{69}$.

${ }^{64}$ El Cristo de la paciencia burgalés es una imagen de roble policromado, vaciada por su parte posterior y concebida para su visión frontal. Los talleres brabanzones trabajaron especialmente esta temática que facilitó el culto a episodios pasionistas en el interior de las iglesias. Vid. R. DIDIER, "A propósito de la escultura en los antiguos Países Bajos al final de la Edad Media”, Lumen Canariense, I, pp. 103-105; y J. YARZA LUACES, "Cristo, varón de Dolores", Tesoros de la catedral de Burgos. El arte al servicio del culto, Burgos, 1995, pp. $100-101$.

65 El éxito de estas esculturas se extendió por toda Europa incluida las islas de Madeira y Canarias (Lumen Canariense, I, p. 38).

${ }^{66}$ Estas figuras podían asirse a unas peanas, donde se pirograbaron algunos poinçons, y guardarse en arquetas cuando no eran objeto de culto. Vid. R. DIDIER, "Nino Jesús", Lumen Canariense, II, p. 178.

67 Un ensayo sobre esta pieza en J.M. CASADO PARAMIO, "Niño Jesús", Comercio, mercado y economía, 2004, pp. 208-209.

${ }^{68}$ Fue común en el caso de las esculturas de pequeño tamaño incluir varias -bastantes- unidades en un mismo contenedor. Uno de los primeros, y casi únicos, acercamientos al tema en F. VERMEYLEN, op. cit., 2003, p. 122.

69 Tales infortunios pervivieron en el tiempo como apreciamos en los avatares sufridos por una colección salida del taller de Zurbarán en su viaje trasatlántico: J.M. PALOMERO PÁRAMO, "Notas sobre el taller de Zurbarán: un envío de lienzos a Portobelo y Lima en el año 1636”, S. GARCÍA (ed.), Extremadura en la evangelización del mundo, Madrid, 1990, pp. 313-330. 


\section{Protocolos notariales y contratos artísticos}

La producción artística bajomedieval, además de acomodarse al modo estandarizado, también pudo responder a un encargo previo donde las intenciones propagandísticas, catequéticas o personales del comitente quedaban exteriorizadas de forma más precisa. En este contexto, ubicamos los contratos artísticos ${ }^{70}$. Muchos están publicados; otros permanecen inéditos en los fondos de los archivos; un número indefinido se han perdido a consecuencia del vandalismo patrimonial ejercido durante siglos y un abanico escaso, de forma aleatoria, pueden aparecer en las casas de subasta como bienes preciados de colección. En este sentido, por su reciente actualidad, queremos hacernos eco de la subasta celebrada en noviembre de 2009 en la casa Christie's sobre el contrato del sepulcro de Mayor Guillén de Guzmán, vinculada a Alfonso X de Castilla. La desaparición del monumento funerario en la Guerra Civil española convierte a unas antiguas fotografías y, sobre todo, al recuperado contrato en los únicos testimonios conservados de este monumento tumular gótico castellano ${ }^{71}$.

Un contrato es un protocolo notarial o documento avalado por un notario. Ese carácter explica su rígida redacción donde advertimos unas cláusulas iniciales y finales que datan el encargo e identifican al contratante -el promotor/es artístico/ $\mathrm{s}^{72}-\mathrm{y}$ al contratado -artífice/s-. Así ocurre con el relativo a las "camas" alabastrinas de Álvaro de Luna y Juana de Pimentel (1489) encargadas, según reza el documento de archivo, al "entallador de imaginería Sebastián de Toledo" por la duquesa del Infantado e hija de ambos, María de Luna, para la capilla familiar situada en la girola de la catedral de Toledo. El hallazgo del manuscrito terminó con el baile de nombres a los que se adjudicaba la obra tumular, a la par que proporcionó unas indispensables coordenadas para el conocimiento de la personalidad del comitente y la motivación del encargo (fig. 6) . $^{73}$.

70 El valor de los contratos como fuente para el historiador del arte ha sido resaltado en diferentes ocasiones, recientemente por J.V. GARCÍA MARSILLA en un espléndido trabajo centrado en el ámbito valenciano: "El precio de la belleza. Mercado y cotización de los retablos pictóricos en la Corona de Aragón (siglos XIV y XV)", C. DENJEAN (ed.), Sources seríelles et prix au Moyen Âge, Toulouse, 2009, pp. 253-290. Una diferente localización geográfica tiene el texto de M.O'MALLEY, The business of art. Contracts and the commisioning process in renaissance Italy, New Haven/London, 2005. La autora plantea una inteligente y variada reflexión que incluye tanto aspectos genéricos -tasación o mercados- como otros más precisos de carácter estrictamente material -pigmentos-, vinculados al modo de producción o de naturaleza estrictamente terminológica.

71 El contrato del sepulcro de doña Mayor, procedente del convento de clarisas de Alcocer, alcanzó la cantidad de 10.000 libras (CHRISTIE'S. Subasta 23 de noviembre de 2009 -Lote 111. 5829 http://www. christies.com/LotFinder/lot_details.aspx?intObjectID=5267930).

72 Dentro de esta casuística general, hay notable matices. Por ejemplo, el contrato referido al retablo mayor de la catedral de Tudela de 1487 ofrece un exhaustivo listado de las personas involucradas en el proyecto. La enumeración de este personal fecha con una cierta precisión el establecimiento de los pintores Diego de Águila y Pedro de Oviedo en la ciudad navarra. Vid. C. FERNÁNDEZ-LADREDA et alii, El retablo mayor de la catedral de Tudela. Historia y conservación, Pamplona, 2001, pp. 75-76.

${ }_{73}$ Madrid, Archivo Histórico Nacional (en adelante: AHN), Osuna, leg. 1793, n 66. Pub. J.M. AZCÁRATE, Colección de documentos para la historia del Arte en España, 2. Datos histórico-artísticos de fines del siglo XV y principios del XVI, Zaragoza-Madrid, 1982, nº 428, pp. 242-244. 


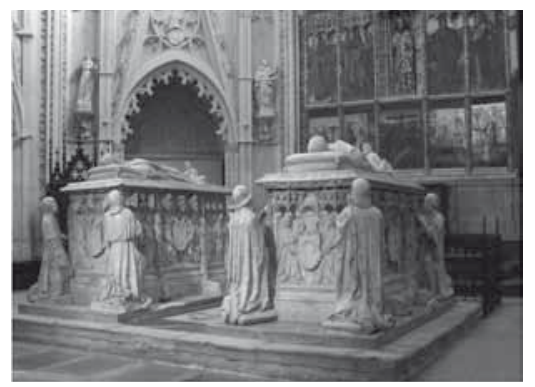

Fig. 6. Sebastián de Toledo, Sepulcros de Álvaro de Luna y Juana de Pimentel, 1489 (Capilla funeraria de Álvaro de Luna, Catedral de Toledo).
Las firmas de los testigos, artistas y fiadores aparecen especificadas en la cláusula final de estos protocolos. Dado el elevado porcentaje de analfabetismo, podían estampar su rúbrica personas autorizadas en nombre de los artífices. Estos últimos, además, elegían a uno o varios fiadores con capacidad para responder ante posibles incumplimientos de su trabajo $^{74}$. El contrato suele terminar con un párrafo definido donde el notario, tras indicar su nombre, señala taxativamente que estuvo presente en el acto mediante la frase "a petición de los interesados redacté, firmé y terminé".

Entre ambas disposiciones, se establecen unas cláusulas intermedias referidas a aspectos temáticos, materiales y salariales.

La iconografía merece una atención precisa en los contratos. Las citas pueden ser someras, alusiones genéricas a las "historias" de la obra, o muy aquilatadas con el enunciado de los temas a desarrollar pudiéndose incluir matices específicos de la representación iconográfica. De este modo, sabemos que el pintor Ferrer Bassa, en el protocolo relativo a las pinturas de la capilla de San Miguel del Monasterio de Pedralbes (1346), asumió la ejecución de un ciclo dedicado a los Gozos de la Virgen "con buenos colores" y otro de tinte pasionista que incluía desde la escena del Prendimiento a la de la Piedad ${ }^{75}$. Ilustran, asimismo, este aserto los documentos referidos al Retablo de la Coronación (1453) donde el pintor Enguerrand Quarton, entre otros asuntos, se obligó a representar al Padre y al Hijo de la imagen trinitaria de forma idéntica ${ }^{76}$ o el relativo a un tríptico -hoy perdido- que Diego de la Cruz realizó para la localidad de Santo Domingo de la Calzada con la exigencia de pintar

${ }^{74}$ En un entorno rural o parroquial, los fiadores normalmente procedían del entorno familiar y su compromiso estribaba mayoritariamente en la conclusión del proyecto iniciado. Tal circunstancia no siempre ocurría en un contexto urbano; de tal forma, sabemos que en el acuerdo para el retablo de la capilla de la universidad de Salamanca de Juan de Flandes actuó como fiador el platero Juan de Dueñas, "ansy para los dineros que recibiere de la dicha obra, como para que la dicha obra será muy buena a contentamiento de la dicha Universidad" (Cit. I. VANDEVIVERE, "Santa Apolonia y Santa María Magdalena", Juan de Flandes, Madrid, 1986, pp. 79-80).

75 La publicación del contrato en J. YARZA LUACES et alii, Fuentes y documentos para la historia del Arte. Arte Medieval II: Románico y Gótico, Barcelona, 1982, p. 86. El análisis de las pinturas en M. SAGUÈ I GUARRO, Ferrer Bassa. Les pintures de la capella de Sant Miquel al monestir de Pedralbes, Barcelona, 1989. Y sobre su relación con la pintura italiana: R. ALCOY, "Barcelona sota el signe de Giotto? Mirades $\mathrm{i}$ arguments", R. ALCOY et alii, El Trecento en obres. Art de Catalunya i art d'Europa al segle XIV, Barcelona, 2009, pp. 49-90.

76 “... y del Padre al Hijo no debe haber ninguna diferencia, y el Espíritu Santo en forma de paloma y Nuestra Señora delante, según como parezca mejor a nuestro maestro Enguerrand...”. Cit. J. YARZA LUACES, Fuentes para la Historia del Arte I, Madrid, 1997, pp. 287-290. 
a San Sebastián, no con sus genuinos atributos, sino "como caballero con una cruz en la mano"77.

Los gestos y expresiones de las figuras también pueden aparecer señaladas en las prescripciones notariales. De tal modo, en el contrato de los sepulcros de Alonso de Velasco y su mujer (1467) para su capilla sita en el monasterio de Guadalupe se exigía al maestro Egas Cueman hacer "dos bultos de ymágines puestos de rodillas" indicando que "... los bultos han de estar de tal continencia conmo si estouiesen resando"78. Apreciemos como la cita contractual pretende trasladar al imaginario artístico los modos demandados en la práctica de la devotio moderna, lo que justificaría la presencia de sendos reclinatorios y libros de oración. Nada queda de estas piezas, detalladamente mencionadas en el contrato, habiéndose sugerido su probable carácter móvil y una hechura de madera ${ }^{79}$.

Unas similares disposiciones restrictivas figuran en el aludido contrato de la tumba de Álvaro de Luna. El documento delimita con una modélica minuciosidad todos los aspectos integrantes de la misma: la postura yacente del finado, la colocación de un paje a los pies en actitud llorosa, la distribución de los elementos heráldicos -los escudos de la Orden de Santiago y los de la casa Luna- y, sobre todo, su elemento más original, los cuatro caballeros genuflexos de la Orden de $\operatorname{Santiago}^{80}$ (fig. 6). La misma afirmación es aplicable al protocolo referido al retablo pictórico que Sancho de Zamora, Juan de Segovia y Pedro de Gumiel realizaron para el mismo ámbito funerario (1488). Las capitulaciones regulan el tamaño, la compartimentación y, especialmente, la temática; mas mientras las tablas de carácter hagiográfico vinculan sus "hystorias" a un documento posterior, la redacción resulta significativamente precisa al referir la apariencia de las imágenes de Álvaro de Luna y su mujer Juana de Pimentel ${ }^{81}$. Sirva de ejemplo, lo regulado en relación a esta última:

"Iten en la pieza de la mano izquierda, la señora condesa de Montalbán fincada de rodillas con sus tocados honestos como su señoría solía traer e un mongil de terciopelo... e sobre un rico sitial de brocado sobre sus almohadas de brocado".

77 Cit. P. SILVA MAROTO, Pintura hispanoflamenca castellana: Burgos y Palencia. Obras en tabla y sarga, Junta de Castilla y León, I, 1990, p. 83.

78 G. RUBIO y I. ACEMEL, "El maestro Egas en Guadalupe", Boletín de la Sociedad Española de Excursiones, XX (1912), p. 207.

79 No sabemos las razones que apoyan estos comentarios, mas queremos incidir en la contundencia de estos muebles auxiliares que, según la información de un documento posterior, tenían su correspondiente policromía: "Dos fasistores que se han de faser en que han de estar las almohadas e libros de resar que sean dorados e las almohadas blancas de damasco, las borlas e caireles sean de oro, los libros el uno azul e el otro verde e los cantos de las fojas de oro" (RUIBO y ACEMEL, op. cit., 1912, pp. 214-125 y 217).

${ }^{80}$ En su pendant, el túmulo de la condesa de Montalbán, los caballeros son sustituidos por frailes. Las derivaciones memoriales de este contrato y su plasmación plástica en O. PÉREZ MONZÓN, "La imagen del poder nobiliario en la Castilla medieval. El arte y las Órdenes Militares en el tardogótico", Anuario de Estudios Medievales, 37, 2 (2007), pp. 907-956.

81 "En cada pieza -indica la cláusula- su imagen, que las mande dar su señoría por relación de las que su señoría le plasiera" (AHN, Osuna, leg. 1734, n 4.3). 
Tal disparidad de comentarios no debe pasar desapercibida ya que, en los contratos, algunas cuestiones quedaban abiertas mientras que otras, en función del interés del comitente, podían constreñir notablemente la creatividad artística ${ }^{82}$. En los dos casos elegidos como ejemplo, subyace la comitencia de María de Luna y su interés por prestigiar la buena memoria de su padre tras una muerte acaecida de forma deshonrosa ${ }^{83}$.

Las referencias a la materialidad propia de la obra son abundantes ya que, y esa condición no ha de sorprendernos, los contratos revelan el íntimo aprecio otorgado en la época a la constitución del objeto artístico y la relación directa existente entre el tamaño, el material empleado y el coste definitivo del mismo ${ }^{84}$. Cotejamos esa afirmación en aspectos como:

- Las frecuentes alusiones al tamaño de la obra, empleando como medidas habituales los pies, los palmos y las varas ${ }^{85}$. La insistencia en la envergadura de la misma atiende a criterios diversos que incluyen, como norma habitual, la obligación del artífice de entregar la pieza terminada y asentada en su emplazamiento respectivo ${ }^{86}$.

- El pesaje y las referencias a la pureza del material en objetos de artes suntuarias $^{87}$. Corroboramos este aserto en el contrato de la cruz de Santa María

${ }^{82}$ Suscribe esta misma casuística el protocolo del citado retablo salmantino de Juan de Flandes conformado por "ocho historias e seys imágenes". La concreción iconográfica se entregaría al pintor en un documento aparte por los maestros de Peñafiel y fray Pedro de León (I. VANDEVIVERE, op. cit., 1986, p. 79).

${ }^{83}$ La biografía del poderoso valido, posteriormente edulcorada en el romanticismo, con el análisis de su comitencia artística en E. FERNÁNDEZ GONZÁLEZ, "Don Álvaro de Luna, condestable de Castilla y maestre de Santiago: hombre de su tiempo y promotor de las artes", La nobleza peninsular en la Edad Media, León, 1999, pp. 135-170; y M.A. CORTES ARRESE, "Los espacios funerarios en los conventos de Órdenes Militares", Del silencio de la cartuja al fragor de la orden militar, Aguilar de Campoo, 2010, pp. 235-254.

${ }^{84} \mathrm{El}$ artífice podía encargarse de la adquisición del material o recibirlo de manos de sus comitentes. Así ocurrió en el contrato de la Maestà de Siena quedando el pintor Duccio sólo obligado a aportar su persona y su trabajo (M. O’MALLEY, op. cit., 2005, p. 75).

${ }^{85}$ La relación de las dos primeras medidas con la última justifica también su respectiva denominación de tercia o cuarta. No obstante, conviene insistir en que, en los distintos reinos peninsulares, existieron pequeños cambios relativos al valor preciso de esos términos. Vid. M. MIQUEL JUAN, op. cit., 2008.

${ }^{86}$ Por compromiso contractual, el tamaño de los sepulcros de Álvaro de Luna y Juana de Pimentel tenía que ser de "seis palmos de alto poco más o menos, desde el suelo hasta la cabeza de la cama y diez palmos de longitud y cuatro palmos de anchura" conminando al artífice a entregarlo en un año "acabado y asentado" en la capilla toledana. La cita resulta especialmente relevante si consideramos que el entallador, asimismo, asumía la realización de las camas alabastrinas en Guadalajara, ciudad donde residía la comitente. Desgraciadamente, no conservamos los documentos relativos al traslado de estas piezas a la urbe toledana pero, por otras citas documentales, sabemos que estos trayectos llegaron a computarse de forma independiente. Así se deduce de los 570 mrs. cobrados por Diego de la Cruz por “poner e asentar” el retablo de Santa Catalina y las Ánimas del Purgatorio en la parroquia de San Esteban de Burgos. Cit. P. SILVA MAROTO, op. cit., 1990, I, p. 83.

87 El pesado de los materiales buscaba evitar el uso de materiales de inferior aleación y los posibles engaños derivados de este hecho. Bajo este prisma, entendemos las leyes dictadas en las Partidas de ALFONSO $\mathrm{X}$ con la condena a las fusiones fraudulentas -“... mezcla de oro y plata con otros materiales”- y el castigo "a pagar las piedras y otras cosas que quebrantan [los orfebres] por su culpa o mengua de sabiduría" (Partida VII, Título VII, Ley II y Partida V, Título VIII, Ley X). 
de Cervera, comisionada al platero Bernat Llopart en 1435, y su peso de 36 marcos de plata realizándose lo restante en plata rota ${ }^{88}$.

- El requerimiento de especiales calidades que, si bien cualificaban la obra, encarecían el montante final de la misma. Para los retablos, los contratos suelen especificar desde la técnica hasta la cantidad, calidad y ubicación de los colores más costosos como el pan de oro o el azul de ultramar a través de los que se evidenciaba la magnificencia de la pieza ${ }^{89}$. Las capitulaciones del retablo de la capilla de los Luna significan el empleo de "oro fino y bruñido..., fino azul e carmesí fino..., e de muy finos colores a olio" conforme a las "gentiles ordenanças nuevas" 90 . En obras escultóricas, las peticiones afectaban a la categoría de las maderas ${ }^{91}$. Recordemos que, en los países mediterráneos, las más usadas eran las de las coníferas frente a las más preciadas de haya, roble o nogal, consumidas habitualmente en Centroeuropa. De tal forma, conocemos la imposición del cabildo de Barcelona al escultor Pere ça Anglada de comprar en la ciudad de Brujas madera de roble para la realización del coro de la catedral $(1394)^{92}$.

Las prescripciones del cabildo catalán incluían un "viaje de formación" destinado a la contemplación y análisis de otros coros ya realizados. La cita no es anecdótica al referir una práctica habitual en los contratos: la referencia a una obra ya ejecutada y tomada en ciertos aspectos como modelo ${ }^{93}$. Las capitulaciones del sepulcro de Álvaro de Luna señalan, con esa particularidad, "el bulto de Alcalá del

88 A. DURÁN I SANPERE, “Orfebrería catalana. I. La creu de Sant Nicolau de Cervera", Estudis Unviersitaris Catalans, VIII (1914), 148-166. Cit. J. YARZA LUACES, op. cit., 1997, pp. 285-287.

89 A través de los datos de la época, observamos la diferencia existente entre el azul de ultramar -material de importación y de elevado precio- del llamado azul de Alemania, empleado en obras de menor coste o en los guardapolvos, y cuantificamos el alto precio de los dorados tanto por el valor de la materia prima como por las dificultades de su aplicación. Una aproximación a la diversidad de pigmentos y su valor crematístico en J.V. GARCÍA MARSILLA, op. cit., 2009, pp. 260-264; y S. KIRBY, S. NASH, J. CANNON (ed.), Trade in artists' materials. Market and commerce in Europe to 1700, London, 2010.

90 AHN, Osuna, leg. 1734, nº 4.3.

91 Subrayamos la precisión realizada por J.V. GARCÍA MARSILLA de emplear como criterios medidores de la madera, además del árbol de procedencia, su correcta manipulación y la destreza en el ensamblaje de las tablas (op. cit., 2009, p. 258).

92 Cit. J. YARZA LUACES et alii, op. cit., 1982, p. 90. El caso no fue un unicum. En fechas coetáneas, el cabildo de Zaragoza exigía al escultor Pere Johan utilizar un alabastro de calidad en el retablo de la catedral. La elección, nuevamente, significó desatender canteras más cercanas que no ofrecían la excelencia buscada. Vid. M.R. MANOTE I CLIVILLES, “Aproximación a la figura del escultor catalán en la Baja Edad Media”, Cathalonia. Arte gótico en los siglos XIV-XV, Madrid, 1997, p. 61; M.R. TERÉS I TOMÁS, "Pere Sanglada i l'arribada del gòtic internacional a Barcelona", L'Art Gòtic a Catalunya. Escultura II. De la plenitud a les darreres influències foranes, Barcelona, 2007, pp. 36-56.

93 Este hecho se inscribe en una época que valora notablemente la calidad y habilidad técnica; en ese sentido, la referencia a una obra ya admitida y apreciada se consideraba como una garantía de éxito. También el viaje facilitaba la percepción de la novedad, en palabras de Francesca Español, actuaba "como vía de conocimiento". Vid. la interesante reflexión que plantea la autora en F. ESPAÑOL, "La transmisión del conocimiento artístico en la Corona de Aragón (siglos XIV-XV)", Saber y conocimiento en la Edad Media, 5 (1997), pp. 73-114. 
arzobispo" 94 ; mientras que al pintor Nuño González se le conmina a realizar "una imagen de Santiago con su frontal e tabernáculo" para Belorado (Burgos) "a vista de lo de Sant Bernabé que está en la dicha iglesia" (1441) o a Juan González de Frías un retablo para la capilla de San Juan de la catedral burgalesa "según está un retablo en el monasterio de san Pablo en el altar de santo Domingo" (1437) ${ }^{95}$. Tampoco fue extraño pautar la responsabilidad específica del maestro. En el retablo de Santo Domingo de Daroca (1474), el maestro Bartolomé Bermejo se obliga a "fazerlo de su propia mano" 96 . ¿Extrañeza por estas precisiones? No. El reconocimiento del modo de trabajo en un taller bajomedieval y la prevención de asegurar la autoría de sus máximos responsables en las partes que exigían mayor pericia.

Normalmente, el contrato solía acompañarse con un boceto, dibujo o muestra preliminar donde el artista exteriorizaba el proyecto en ciernes o alguna particularidad del mismo ${ }^{97}$. Las notas de archivo redundan en esta práctica. De tal forma, en el contrato del yacente de Álvaro de Luna, tras una prolífica descripción, se remite al maestro a "un dibujo que dio el alcaide Juan de Córdoba"98 en el relativo al tríptico de Diego de la Cruz "... a un papel que mostró" absidial de la Catedral Vieja de Salamanca a Nicolás Florentino a "las muestras e estorias q. vos [el pintor] mostrades debuxadas en un pergamino"100. En algunos casos, las muestras completaban la información proporcionada por el contrato. Así se colige en el protocolo acordado entre el maestro Egas y el citado Alonso de Velasco: "primeramente ha de abrir un arco en la pared... e este arco ha de levar toda la imaginería e crestería que está fecha en la demuestra que está sennalada"101. Todos los

94 AHN, Osuna, leg. 1793, nº 66.

95 La transcripción de ambos documentos en P. SILVA MAROTO, op. cit., 1990, I, no 70 y 74.

${ }^{96}$ Cit. M.C. LACARRA DUCAY, "Bartolomé Bermejo y su incidencia en el panorama artístico aragonés", La pintura gótica hispanoflamenca. Bartolomé Bermejo y su época, Barcelona, 2003, p. 41. La precisión documental, habida cuenta del funcionamiento de los talleres bajomedievales, constituye una referencia al aprecio otorgado a las habilidades del pintor (J. BERG SOBRÉ, "Sobre Bartolomé Bermejo", Bartolomé Bermejo y su época, p. 20).

97 El nombre de éstos varía según la geografía; en el ámbito valenciano son las mostras [E. MONTERO TORTAJADA, "El sentido y el uso de la mostra en los oficios artísticos. Valencia, 1390-1450", Boletín del Museo e Instituto Camón Aznar, XCIV (2004), 221-254] y en contratos italianos los disegni (M. O’MALLEY, op. cit., 2005, p. 197). Una recopilación de los diseños conservados en M.C. LACARRA DUCAY, "Sobre dibujos preparatorios para retablos de pintores aragoneses del siglo XV", Anuario de Estudios Medievales, 13 (1983), pp. 553-581.

98 AHN, Osuna, leg. 1793, nº 66.

99 Cit. P. SILVA MAROTO, op. cit., 1990, I, p. 83.

${ }^{100}$ En otro epígrafe del citado contrato de 1445 se alude en parecidos términos a la existencia de estos bocetos previos: "E yo el dicho Nicolao florentino pintor, ansy otorgo e conozco por esta dicha carta q. rrescibo de vos los dichos señores Deán e Cabildo a faser e pintar la dicha obra de la dicha capilla del dicho altar mayor de la dicha iglesia desde lo alto fasta lo baxo de las muestras e estorias e debuxo q. ove mostrado e un pergamino e debuxado" (Archivo de la Catedral de Salamanca, cajón 44, leg. 2. Pub. F.J. PANERA CUEVAS, La restauración del retablo de la catedral Vieja de Salamanca, Valladolid, 2000, pp. 233-235).

${ }^{101}$ RUIBO y ACEMEL, op. cit., 1912, pp. 206. Los dibujos conservados en el monasterio firmados por Egas no coinciden exactamente con el contenido del contrato, ni con la obra finalmente realizada. A sugerencia de algunos investigadores, pueden estar vinculados a un primer contrato posteriormente modificado. 


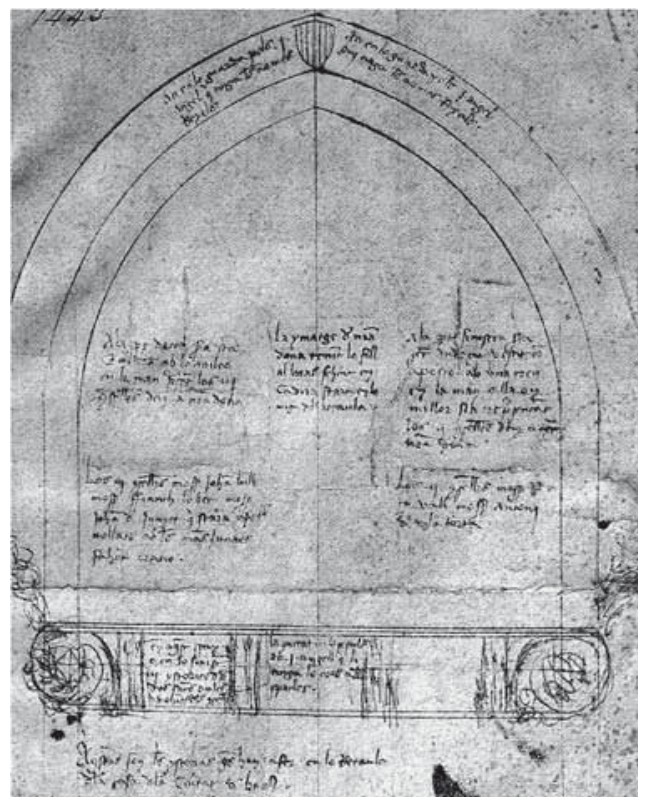

Fig. 7. Lluís Dalmau, Boceto de la Virgen de los Consellers, 1443 (Arxiu Històric de Barcelona).

ejemplos mencionados coinciden en la órbita castellana de los encargos. Desgraciadamente, no subsiste ninguno de ellos. Su consideración como estadios intermedios de utilidad transitoria ha incidido en su escasa conservación ${ }^{102}$, mas cuando esta regla se interrumpe apreciamos el carácter vinculante de estas muestras. Así ocurre con la relativa al encargo de la Virgen de los Consellers de Lluís Dalmau (1443. Arxiu Històric de Barcelona) (fig. 7) ${ }^{103}$. En este caso, más que un modelo a pequeña escala in sensu strictu, el disegni es un bosquejo presentación de los aspectos más particulares de la obra: la predela -hoy perdida-, su infrecuente formato - probablemente derivado de los arcos diafragma de la estancia- y las inscripciones ubicativas de los cinco consellers del Ayuntamiento de la Ciudad en torno a la Virgen entronizada ${ }^{104}$. Precisamente, uno de los ejes nodulares del contrato estriba en la condición de retratos de los efigiados, "effigiiats segons proporcions" 105 .

No obstante, y a pesar de la simplicidad que muchas veces les caracteriza, el valor de estos bocetos, especialmente cuando corresponden a obras no conserva-

${ }^{102}$ Un interesante planteamiento sobre la cambiante valoración otorgada al dibujo y la influencia de esta percepción en su conservación en el catálogo Jan van Eyck. Grisallas, Madrid, 2009.

${ }^{103}$ Apreciamos la misma idea en otros contratos como el del retablo de la catedral de Tudela donde se exigía a Diego de Águila y Pedro de Oviedo "pintar el retablo mayor de la dita yglesia... el gual han de pintar tan sumptuoso, tan perfecto et tan acabado como la tabla que de presente han fecho la qual está sobre el altar" $\mathrm{y}$, en caso de que "no fizieren tal la dita obra como la dicha muestra que sean tenidos e obligados a sus propias despensas tornarla a fazer fasta ser concordante con ella" (Pub. C. FERNÁNDEZ-LADREDA et alii, op. cit., 2001, p. 76).

${ }^{104}$ Un riguroso análisis de esta obra en J. MOLINA I FIGUERAS, Arte, devoción y poder en la pintura tardogótica catalana, Murcia, 1999, pp. 173-228. El autor, asimismo, considera que el cambio introducido en la obra al sustituir los tradicionales dorados demandados en las cláusulas contractuales por los paisajes finalmente ejecutados no debió realizarse sin la aprobación de los consellers (p. 199). El caso tampoco fue excepcional ya que debió ser factible la modificación de los protocolos notariales bien para alterar o bien para completar anteriores disposiciones. Recordemos, en este sentido, la casuística del retablo Luna mencionado en páginas anteriores.

105 "E aprés en la part dreta matexa pinterá tres dels dits honorables Consellers, ço es, mossen Johan Llull, mossen Francesca Llobet e mossen Joahn de Junyent.... E aprés en la dita part esquerra matexa sien pintats e effigiats los dos Consellers, ço es, mossen Ramon Savall e mossen Anthoni de Vilatorta" (S. SANPERE, Los cuatrocentistas catalanes, II, Barcelona, 1906, doc. IX, p. XV y F. RUIZ I QUESADA, "Virgen de los Consellers”, Bartolomé Bermejo y su época. La pintura gótica hispanoflamenca, Barcelona, 2003, 296-301). 
das, puede ser inestimable. A modo de ejemplo, y aunque no está ligado estrictamente hablando a un contrato, queremos hacer referencia a un dibujo relativo a unos sepulcros perdidos de la Orden de Calatrava ${ }^{106}$. El croquis funciona como un desplegable de tal forma que los emblemas heráldicos corresponden a las cuatro paredes de los monumentos tumulares y las siluetas figurativas reproducen las tapas o lápidas de cerramiento con los finados en posición yacente y el perro simbólico a los pies. La reconstrucción virtual del mismo facilita ampliamente su evocación memorial (fig. 8) ${ }^{107}$. El ejemplo es extensible a otros objetos artísticos, mas queremos subrayar las posibilidades que las nuevas tecnologías ofrecen en la aproximación a la cultura visual del período.

Los bocetos, inclusive, pudieron complementarse con pequeñas maquetas de carácter tridimensional o plantillas. Apreciemos que en el protocolo de la reja de la Capilla Real de Granada (1517) se alude tanto a un dibujo -“... de la raçión e forma que está dada por muestra en un pergamino firmado del dicho señor Antonio de Fonseca e de los dichos Ioham Zaga e Juan de Cuvillana maestros de la dicha rexa"- como a la entrega de una chapa or-

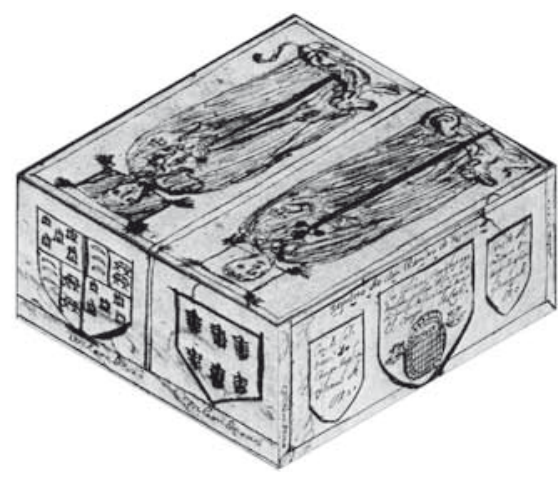

Fig. 8. Reconstrucción virtual del sepulcro de Diego García de Castrillo. Realización: Manuel Martín Rivas. namentada -"ha de tener... seys pilares principales... labrados por todas quatro partes de obra romana conforme a una chapa de fierro labrada... con que las labores de la dicha chapa deben ser más levantadas y más claras" $-{ }^{108}$. El documento no aclara si la chapa se realizó expresamente o no para la obra de metalistería; aunque, como ya ha subrayado García Marsilla en otro contexto y referido a otras obras, parece materializar el valor dado en los contratos a la novedad o a unas corrientes de gusto ${ }^{109}$. Con el dibujo y la maqueta, quedaba perfectamente pergeñada la apariencia visual pretendida.

Una parte fundamental de los contratos era la relativa al salario. Los pagos estaban sujetos a la ejecución de la obra en un plazo convenido, a su instalación y a

\footnotetext{
${ }^{106}$ Los dibujos corresponden a los destruidos sepulcros del primer comendador mayor calatravo Diego García de Castrillo y el clavero Ramiro Núñez de Guzmán sitos en la iglesia del conventual de Calatrava la Nueva. El estudio de los mismos en O. PÉREZ MONZÓN, "Las manifestaciones artísticas como expresión del conflicto", J.M. Nieto Soria (coord.), La Monarquía como expresión del conflicto, Madrid, 2006, pp. 616-620.

${ }^{107}$ La reconstrucción se ha realizado con el programa de diseño AutoCAD. Agradecemos su ejecución a Manuel Martín Rivas.

${ }^{108}$ Simancas, Archivo General de Simancas (en adelante: AGS), CyS Reales, leg. 10, fol. 140.

109 J.V. GARCÍA MARSILLA, op. cit., 2009, p. 272.
} 
la supervisión última de los veedores ${ }^{110}$. De este modo, entendemos que el maestro Egas se comprometiera a entregar su obra tumular extremeña "acabada perfectamente a vista de buenos maestros" $" 111$ o que Sancho de Zamora y Juan de Segovia, tras su compromiso de ejecución anual y colocación in situ, sometieran su pago a "contentamiento de su señoría [la duquesa del Infantado] e de ofiçiales" y aceptaran una posible penalización de 10.000 maravedís por incumplimiento laboral ${ }^{112}$. Juan de Flandes, asimismo, avino la satisfacción monetaria del retablo de Salamanca al "contentamiento de la Universidad y visto bueno de maestros" 113 ; tal demanda, no obstante, no le impidió actuar como veedor de la pieza encargada para el hospital de la misma universidad ${ }^{114}$. Otros contratos, inclusive, regularon los márgenes de variabilidad asumidos por el promotor. En las capitulaciones de la reja granadense, tras precisar sus medidas de 38 pies de altura y anchura, se computa que "si más o menos demandare la dicha obra en el alto o en el ancho, dos pies más o menos, que no aya cuento ny descuento, sino que así lo ayan de haser e cumplir" ${ }^{\text {"115. A las }}$ circunstancias anteriormente mencionadas, hemos de unir la frecuente morosidad, incluso insolvencia en los salarios, el habitual recurso de la vía judicial para obtener las deudas pendientes y su posible percepción tras el fallecimiento del artista ${ }^{116}$.

El pecunio de los artistas podía completarse con una retribución en especie no siendo infrecuente la exigencia de dedicación exclusiva o de residencia obligatoria. El cobro en metálico solía ofrecer diversos matices que incluían desde una cotización global o un precio cerrado a otra más artesanal que valoraba el trabajo por días o figuras ${ }^{117}$. Todo ello nos habla de una diversidad de categorías insertas en el oficio común del artífice medieval y de la dificultad de establecer unos juicios demasiado cartesianos sobre el tema.

${ }^{110}$ El plazo de ejecución estipulado podía influir en la tasación de la obra, igual que los materiales empleados o el número de figuras representadas (M. O’MALLEY, op. cit., 2005, pp. 135-137). Mas no siempre la resolución del contrato se realizó de forma satisfactoria. Por documentos contractuales conservados, advertimos las posibles disidencias entre contratantes y contratados una vez finalizada la obra. P. SILVA MAROTO presta atención a esta casuística (op. cit., 1990, I, p. 82).

${ }^{111}$ RUIBO y ACEMEL, op. cit., 1912, p. 208.

112 Tales penalizaciones, bien por demora o por inadecuación estética, fueron una práctica relativamente común. En el ejemplo mencionado, el escarmiento se descontaría del sueldo prescrito de 105.000 mrs (AHN, Osuna, leg. 1734, $\left.\mathrm{n}^{\circ} 4.3\right)$.

${ }^{113}$ En pocos casos, los veedores se inclinaban al alza -ocurrió en el segundo contrato del retablo tudelense- y aceptaron incrementos de salario. Como nota poco usual, mencionamos el complemento de 15.000 maravedís percibido por el pintor Juan de Flandes (I. VANDEVIVERE, op. cit., 1986, pp. 80-83).

${ }^{114}$ En el contrato de 1508 realizado con el entallador Anton de Lurrena se especifica que "a de ser fecho a contentamiento de la Universidad conforme a la muestra, a vista de maestros e de Juan de Flandes, pintor". Cit. I. VANDEVIVERE, op. cit., 1986, p. 87.

115 AGS, CyS Reales, leg. 10, fol. 140.

${ }^{116}$ Nuevamente podemos poner nombres propios a estos condicionantes: la viuda de Juan de Flandes cobró su postrero trabajo, los familiares de Ordoñez percibieron los últimos sueldos por el sepulcro de Juana la Loca y la liquidación total de Michel Sittow ocurrió después de morir su mentora, Isabel la Católica.

${ }^{117}$ El precio, normalmente, se desglosaba en tres partes: un tercio al inicio de la obra; el segundo, avanzada su ejecución y el tercio restante, tras su conclusión. Las fechas solían coincidir con festividades religiosas. 
Los documentos conservados recogen esta apuntada diversidad. Como corolario de ejemplos, mencionamos que el cabildo de León pagó la vivienda de Nicolás Francés mientras duró la ejecución del retablo mayor de la catedral, las autoridades universitarias ofrecieron a Juan de Flandes "en el hospital de dicho Estudio una muy buena cámara donde esté e viva todo el tiempo que entendiere en pintar la obra" y Diego de la Cruz en el encargo para Santo Domingo de la Calzada recibió "posada, cama e personal que guise" 118 . De otro modo, Egas Cueman cobró de forma individual cada una de las tres figuras de apóstoles labradas para la puerta de los Leones de la catedral de Toledo y Sebastián de Toledo percibió 90.000 maravedís por los reiterados sepulcros de Álvaro de Luna y Juana de Pimentel, descontando para la compra de material una cuarta parte del citado salario ${ }^{119}$. Diversos casos europeos coinciden en la casuística general de este planteamiento ${ }^{120}$.

Por último, no podemos olvidar la existencia de las subcontrataciones que permitían a artistas renombrados satisfacer una amplia demanda de trabajo ${ }^{121}$. Joaquín Yarza sugirió la participación de un artista europeo ignoto en las pinturas de Pedralbes por mandado de Ferrer Bassa ${ }^{122}$ y Matilde Miquel ha ofrecido la transcripción del documento por el que Miquel Alcanyiç y Bartomeu Pomar subcontratan con Felip Porta y Joan de Casa un retablo de Santa Catalina para la iglesia de Castellón de Xàtiva (26 de junio de 1426) ${ }^{123}$. Las condiciones económicas de las mismas fueron heterogéneas teniendo documentados tanto ejemplos que incluyen el cobro de la totalidad del estipendio acordado por parte del artífice subcontratado como otros que contemplan sólo la percepción de un porcentaje ${ }^{124}$.

\section{Valor de la obra de arte en la cultura visual bajomedieval}

Lo anteriormente señalado nos sitúa ante algunos aspectos nodulares relativos a la puesta en valor de la obra de arte bajomedieval. A ellos dedicaremos los siguientes epígrafes.

\footnotetext{
${ }^{118}$ Cit. P. SILVA MAROTO, op. cit., 1990, I, p, 82.

${ }^{119}$ Cit. J. YARZA et alii, op. cit., 1982, pp. 276-277; I. VANDEVIVERE, op. cit., 1986, p. 80; y AHN, Osuna, leg. 1793, nº 66.

${ }^{120}$ Ratifica esta casuística el encargo a Sano di Pietro en 1445 de un altar de San Bernardino (Siena, Museo dell'Opera Metropolitana). La cofradía de la Virgen de Siena, en su calidad de comitente, exigió que el santo franciscano ubicado en la calle central fuese repintado hasta su completa satisfacción. Cit. M. O'MALLEY, op. cit., 2005, p. 88.

${ }^{121}$ Cit. M. O’MALLEY, op. cit., 2005, pp. 90 y ss.

${ }^{122}$ Cit. J. YARZA LUACES, "Ferrer Bassa revisado", Arte d' Occidente temi i metodi. Studi in honore di Angiola Maria Romanini, I, Roma, 1999a, pp. 715-725; F. ESPAÑOL BELTRÁN, El gótico catalán, Barcelona, 2002, pp. 220-221; y R. ALCOY I PEDRÓS, "Ferrer Bassa, un creador d'estil”, L'Art Gòtic a Catalunya. Pintura I. De l'inici al l'italianisme, Barcelona, 2005, pp.146-170.

${ }^{123}$ M. MIQUEL JUAN, op. cit., 2008, p. 293, 182- 190.

${ }^{124}$ M. O’MALLEY, op. cit., 2005, p. 91.
} 


\section{Cuestiones de autoría}

La realidad artística bajomedieval fue poliédrica donde ni todos los maestros tuvieron el mismo predicamento, ni el trabajo artístico siguió unos rígidos corsés. La condición artesanal se antoja idónea para los participantes en los talleres de producción estandarizada: su trabajo en equipo o la repetición de modelos son factores indicativos de esta clasificación. Pero, ¿es factible identificar como artesano a Van Eyck, prestigioso embajador de la corte de Borgoña, o a Juan Guas, poseedor de una vasta capilla funeraria particular, e inclusive, volviendo hacia atrás la mirada, a Giotto nombrado arquitecto comunal de Florencia (1334) como gloria para la ciudad y los ciudadanos? Probablemente, artista sería un término más adecuado pero el término lleva implícitas unas apreciaciones actuales que con puridad plantean ciertas disonancias al aplicarlas al medievo ${ }^{125}$. Todo ello nos lleva a recabar sobre varios aspectos del quehacer artístico de la época.

En primer lugar, ahondar en el modo de trabajo del taller medieval donde la colaboración constituía una práctica asentada. Detrás de un autor de renombre, compete hablar de un taller cuyos miembros participaban en distintos cometidos de la obra. Tal circunstancia explica, como mencionábamos en las páginas previas, porqué en algunos contratos se especifica claramente las partes que debía ejecutar el maestro en una dinámica que, con el tiempo, adquirió una mayor precisión convirtiéndose algunas partes de la producción en materia específica de negociación ${ }^{126}$.

Además, no hay que desatender las restricciones de oficio. Pensemos, básicamente, en las cláusulas contractuales ligadas al formato de las piezas artísticas y expresamente a su iconografía. En los encargos asignados al pintor francés Quarton o al entallador Sebastián de Toledo, por referirnos a dos ejemplos previamente mencionados, las mayores particularidades iconográficas de las obras -la isocefalia de las dos personas de la Trinidad y los caballeros santiaguistas genuflexos- son obligaciones impuestas al artífice. La cuestión nos sitúa en una línea de investigación aún por abordar en su totalidad: los condicionantes establecidos al autor material de la obra. Claros en la producción seriada y, en algunos casos, notables en la producción contractual. Esta precisión ha llevado a considerar el papel del comitente como pagador y poseedor, pero también como autor mental

\footnotetext{
${ }^{125}$ Hace unos años, el profesor Yarza ya planteó una primera y acertada aproximación sobre la múltiple realidad del trabajo artístico en la Baja Edad Media: J. YARZA LUACES “Artista-artesano en la Edad Media hispana”, L'Artista Artesà medieval a la Corona d'Aragó, Lleida, 1999b, pp. 7-58.

${ }^{126}$ Cit. M. O’MALLEY, op. cit., 2005, p. 91. Tampoco podemos olvidar que una obra podía requerir el trabajo de varios oficios. El gremio de escultores de Wurzburgo, al que perteneció Tilman Riehmensheider, prohibía al escultor pintar sus propias obras. Los ejemplos se retrotraen en el tiempo. En el estudio sobre la Porta Picta de la catedral de Laussane (c. 1220) se ha observado que ciertos detalles de la escultura monumental como los ojos o los párpados se dejaron sin acabar y confiaron al trabajo de los pintores. Vid. E. PAGELLA, "Ver, copiar, interpretar: artistas y circulación de modelos en el ámbito eclesiástico", E. Castelnuovo y G. Sergi (eds.), Arte e Historia en la Edad Media. I. Tiempos, espacios, instituciones, Madrid, [2002] 2009, pp. 463-464.
} 
o definidor del diseño. Autoría del comitente que, en determinados casos, implementaría la labor del artífice destinada, en buena medida, a la ejecución material de la obra ${ }^{127}$.

Por último, no podemos obviar que el trabajo artístico incluía quehaceres ciertamente diferentes desde la obra única, fruto de encargos personalizados, hasta intervenciones en arte efímero que afectaban a la creación de escenografías teatrales e insignias ceremoniales -pintura de escudos en recordatorios y decoración de indumentos- o la participación en obras "menores" como la pintura de muebles y estandartes. No es casual que Veit Stoss paralelamente a sus grandes artefactos de retablos, vendiera productos estandarizados en la feria de Frankfurt o que Cennino Cennini en su tratado El libro del arte dedicase varios epígrafes tanto a la obtención de pigmentos o preparación de superficies como al dibujo de los contornos de las figuras o al modo de pintar los estandartes, las cimeras o los blasones y sobrevestes para torneos y justas ${ }^{128}$.

El panorama bajomedieval vuelve a estar definido por la intersección de vectores ya que, si bien es cierto que existieron pintores decorativos que centraron su producción en estas "labores menores", autores de cierto reconocimiento incluyeron en su actividad laboral trabajos axiomáticamente heterogéneos ${ }^{129}$. De tal modo, sabemos que Petrus Christus, afamado retratista y pintor, supervisó el attrezzo de un Árbol de Jessé colocado en la ciudad de Brujas ${ }^{130}$ y que Nicolás Francés paralelamente a su labor en retablos, vidrieras y libros miniados policromó un faraute para la gesta caballeresca del Paso Honroso de Suero de Quiñones ${ }^{131}$.

Apreciamos, pues, como son varias las cuestiones abiertas sobre la obra medieval y sus protagonistas y, paralelamente, percibimos los déficits con los que contamos. Déficits ligados, en buena medida, a las carencias -inclusive vacíosdocumentales. Tales hiatos, especialmente advertibles en la Corona de Castilla, otorgan un valor prioritario a la información proporcionada por las cláusulas contractuales donde la identidad de un artífice, además de por su referencia nominativa, puede implementarse a través de otros datos ligados a su lugar de nacimiento y residencia, la tenencia de un taller y la mención de una obra realizada o por realizar. Nuevamente, los ejemplos resultan ilustrativos. En 1418, a Pere

\footnotetext{
${ }^{127}$ Entendida la autoría como ese amplio paraguas podemos evaluar de forma más precisa las disposiciones contractuales alusivas al léxico, los materiales empleados o las citas a obras ya consagradas.

${ }^{128}$ Precisamente, en las instrucciones relativas a este último apartado, el pintor aconseja sobre el modo de "hacer animales, flores, rosas y muchos blasones diferentes" para que el artífice pudiera "ganar gran fama" (CENNINO CENNINI, El libro del arte, F. BRUNELLO (ed.), Madrid, 2000, p. 208). El reconocimiento ciudadano parece no estar ajeno a estos menesteres que acercaban el trabajo artístico a facetas múltiples de la cotidianeidad.

${ }^{129}$ Una valoración en profundidad del tema en M. MIQUEL JUAN, op. cit., 2008, pp. 201-218.

${ }^{130}$ Cit. M.W. AINSWORTH y M.P.J. MARTENS, Petrus Christus. Renaissance Master of Bruges, New York, 1994, p. 14.

${ }^{131}$ Cit. J. YARZA LUACES, op. cit., 1999b, p.26.
} 
Johan se le designa "imaginero residente en Barcelona", a la par que se le califica de "muy apto" para realizar la chambrana sobre el San Jorge de la Diputación ${ }^{132}$; mientras que, en 1446, Alfonso I de Aragón al solicitar los trabajos de Dello Delli en el Castel Nuovo de Nápoles resaltaba "la singularidat de ingenio e perfeccion de su arte... specialmente acerca de geometría e otras sciencias demostrativas"133. Del mismo tenor, resulta el contrato del retablo del Hospital universitario de Salamanca (1508); en él se elige a Juan de Flandes como "excelente pintor" reclamándole que lo haga "tan bueno en perfección como el de las Escuelas"134. Estimemos como en estos documentos aparecen unas sincopadas "biografías" de autor ciertamente interesantes, si consideramos la escasa definición que aún tenía el género de la literatura de artistas. Además, en la redacción de los mismos subyacen unas indicaciones de categoría profesional extraordinariamente ricas en matices. En individualizados contratos, Jean Lome figura como "maestro de hacer las imágenes", Pere Johan como "escultor de imágenes" o Sebastián de Toledo como "entallador de imaginería" 135 . Las obras encargadas atañen a lo que hoy consideramos genéricamente labor escultórica -relieves monumentales y monumentos tumulares-, mas al insistir en la habilidad de los artífices en la ejecución de imágenes -figuras- priorizan su categoría sobre la de otros maestros decorativos. Resta concluir señalando que detrás de estas etiquetas subyace una jerarquía profesional, no exenta de vasos comunicantes, que requiere todavía una investigación detallada.

\section{Originalidad y/ o copia}

Por último, los documentos de la época plantean una poliédrica casuística que incluye desde la elaboración de diseños impactantes y novedosos hasta la repetición de composiciones famosas o afortunadas, el empleo como exemplum de dibujos y grabados previos o la frecuente cita contractual de tomar como referencia una obra ya realizada y aplaudida. Hablamos, nuevamente, de dos realidades que coexisten en los siglos bajomedievales: la originalidad y la afición a la copia ${ }^{136}$.

Antes de avanzar, conviene señalar las disidencias historiográficas postuladas en torno a los términos copia y réplica. Algunos autores consideran que son palabras

\footnotetext{
${ }^{132}$ En el texto, de forma pormenorizada, se le señala como autor de esta escultura: “...por orden nuestra habéis fabricado y tallado en piedra la imagen de San Jorge" (Cit. J. YARZA LUACES et alii, op. cit., 1982, pp. 274-275).

${ }^{133}$ Archivo de la Corona de Aragón, reg. 2654, fol. 42v. Pub. F.J. PANERA CUEVAS, op. cit., 2000, pp. 235-236.

${ }^{134}$ Cit. I. VANDEVIVERE, op. cit., 1986, p. 87.

${ }^{135}$ Cit. J. YARZA LUACES et alii, op. cit., 1982, pp. 272-275.

${ }^{136}$ Un imprescindible punto de partida sobre el tema, abordado en un espectro cronológico más amplio, en S. MORALEJO, "Modelo, copia y originalidad, en el marco de las relaciones artísticas hispano francesas (siglos XI-XIII)", V Congres Espanyol d'Historia de l'Art, I, Barcelona, 1986, pp. 89-112.
} 
sinónimas, mientras que otros matizan su significado considerando la réplica como la copia de una obra realizada por el mismo autor ${ }^{137}$ e inclusive como una copia con licencias o ciertas diferencias visibles ${ }^{138}$. Dejando de lado, con ser importantes, cuestiones semánticas; la cuestión clave es la afición por la copia; inclinación que en términos de la cultura visual de la época carecía de una dimensión peyorativa y que juzgamos ligada a varios principios enhebrados intrínsecamente ${ }^{139}$ : prácticas de taller, reconocimiento de autoría/prestigio de una obra y copia con dimensión memorial.

\section{A) Prácticas de taller: tradición de libros de modelos}

Uno de los grandes apartados de la literatura técnica medieval fue la llamada literatura de modelos conformada por un repertorio de dibujos que podían incluir desde detalles ornamentales a colecciones de bestiarios o gestos humanos pasando por siluetas de figuras y completas composiciones iconográficas ${ }^{140}$.

Tales dibujos constituían uno de los bienes más preciados de los talleres. Suponían años de trabajo, adquisición y recopilación. Formaban parte del equipaje del artífice en su itinerancia laboral, no descartándose el intercambio de ciertas láminas entre profesionales en el oficio. Podían presentarse sueltos, agrupados o guardados en cajas. Su uso fue múltiple. Se empleaban como medio de aprendizaje o de ejercitación en el oficio por los ayudantes, a modo de exemplum ${ }^{141}$. También, como archivo de diseños de taller que actuaban a modo de prototipos y por consiguiente facilitaban la génesis del trabajo ${ }^{142}$. Y, finalmente, actuaron a modo de repertorio de opciones que el taller ofertaba a un posible cliente ${ }^{143}$.

${ }^{137}$ Según las palabras de P. Silva Maroto, el fenómeno de la copia fue una práctica común en los Países Bajos durante los siglos XV y XVI siendo frecuente que "el propio artista realizara réplicas de algunas de sus obras" (El Jardín de las Delicias de El Bosco: copias, estudio técnico y restauración, Madrid, 2000, p. 27).

${ }^{138}$ Suscribe esta última acepción S. CABALLERO ESCAMILLA, "Función y recepción de las artes plásticas en el siglo XV", Norba-Arte, XXVI (2006), p. 30.

${ }^{139}$ Centramos nuestro discurso en la esfera de lo artístico; aunque conviene remarcar el uso común de la copia y los exemplos en el medievo, bien en composiciones musicales, relatos literarios de milagros o en el género cronístico.

${ }^{140}$ Sobre el tema, resulta obligada la consulta del texto de R. SCHELLER, Exemplum. Model book drawings and the practice of artistic transmission in the Middle Ages (ca. 900-ca.1450), Amsterdam, 1995.

${ }^{141}$ Como puntualiza H. MUND el aprendizaje se realizaba tanto mediante la copia de los dibujos como de las tablas pintadas ("Original, copy and influence, a complex issue", Roger van der Weyden, master of passions, Lovain, 2009, p. 190).

${ }^{142}$ Actuaban, por consiguiente, como elemento de aprendizaje pero también de inspiración o experimentación. La copia podía afectar tanto a la totalidad de la escena como a ciertas figuras o detalles compositivos que se incluían a modo de citas pudiendo realizarse ciertas variantes del modelo original. Tales usos, como subrayábamos en la nota anterior, afectaban no sólo al dibujo sino a las composiciones originales. Vid. M. HOLCOMB, "Strokes of genius. The draftsman's art in the middle ages", Pen and Parchment. Drawing in the Middle Ages, New York, 2009, p. 26; y Jan van Eyck, 2009, p. 65.

${ }^{143}$ Precisamente, este uso explica que a fines del período existieran de libre circulación corpus de relicarios concebidos a modo de libros de modelos para satisfacer los gustos de una demanda creciente. Su análisis excede el marco de esta exposición pero es un claro indicio de los difusos límites que en la Edad Media 
Conservamos repertorios de dibujos realizados en pergamino, papel, madera o textil. Ejemplifica esta práctica un $\mathrm{Va}$ demecum bohemio de principios del siglo $\mathrm{XV}$ conformado por más de 50 dibujos de caras sobre papel montados sobre paneles de madera (fig. 9). Todos ellos atendieron a diferentes propósitos; algunos podían copiarse y yuxtaponerse codificando un repertorio de bestiario útil para ciertas escenas bíblicas como la Creación de los Animales o la Cabalgata de los Magos; otros, sencillamente podían unirse y formar recurrentes imágenes devotas léase una Piedad, un San Juan afligido o una Crucifixión ${ }^{144}$; no faltando la presencia de calaveras tan caras al gusto tardogótico. La lista podría completarse con otros nombres y obras debiendo también incorporar el abecedario de modelos, letras capitales ornadas con los motivos iconográficos propios del momento como las Letras góticas de Giovannino de Grassi (1380-1400. Biblioteca Cívica,

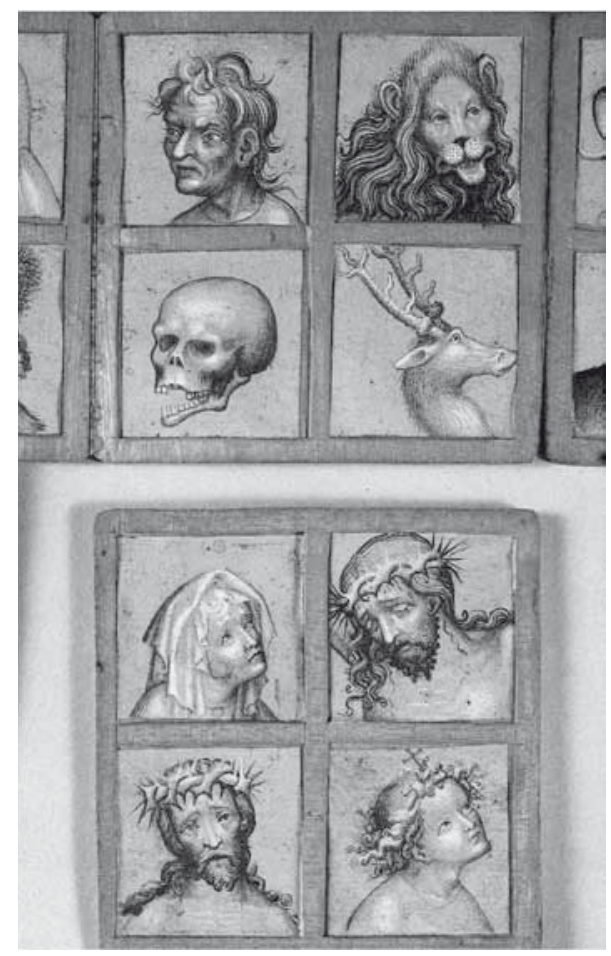

Fig. 9. Anónimo, Vademecum bohemio, siglo XV (Kunsthistorisches Museum, Viena, inv. ${ }^{\text {os }}$ 5003-5004). Bérgamo $)^{145}$. Apreciemos que los motivos utilizados en buena medida son deudores de los que pueblan el arte monumental; en el caso de la $\mathrm{K}$ se estructura en torno a tres figuras de salvajes.

La estela de los libros de modelos fue continuada por los grabados que, debido a los beneficios derivados de su reproducción mecánica, incorporaron un mayor nivel cuantitativo de difusión ${ }^{146}$. La recepción de grabados en la Cas-

existió entre las esferas de lo religioso y lo profano. El análisis devocional de esta lámina en P. MARTíNEZBURGOS GARCÍA, "Libro de los santos", Erasmo en España. La recepción del Humanismo en el primer renacimiento Español, Madrid, 2002, p. 319.

${ }^{144}$ Un análisis en profundidad de este vademécum ha revelado diferentes manos de calidad y añadidos posteriores (Exemplum, pp. 227-233). El valor del mismo ya fue señalado por C. HARBISON, El espejo del artista. El arte del Renacimiento septentrional en su contexto histórico, Madrid, [1995] 2007, p. 70.

${ }^{145}$ R. SCHELLER, op. cit., 1995, p. 278. Uno de los más antiguos libros de modelos tipo abecedario data del último tercio del siglo XII. Le caracterizan sus capiteles de formas zoomorfas cuajadas de decoración vegetal (M. Holcomb, "Model book of initials", Pen and Parchment, pp. 120-123).

${ }^{146}$ Sobre el tema han trabajado I. MATEO GÓMEZ, "Panorama de la pintura del Renacimiento e influencias del grabado alemán en España", Grabados alemanes de la Biblioteca Nacional (siglos XV-XVI), Madrid, 1997, pp. 13-24 y C. HUIDOBRO, "Los primeros grandes creadores del grabado en los Países Bajos", Grabados flamencos y holandeses del siglo XVI, Madrid, 2004, pp. 12-57. 
tilla del siglo $\mathrm{XV}$ fue ciertamente significativa. Como han señalado recientes estudios, a través de las ferias y del fluido comercio marítimo llegaron un importante número de estampas coleccionadas por unos, Fernando Columbus entre otros ${ }^{147}$, o empleadas por maestros como elemento de inspiración al participar de un gusto común a la época ${ }^{148}$. Martín Schongauer (c. 1430-1491) fue un buen pintor pero, especialmente, el creador de un ciclo de imágenes neotestamentarias de carácter pasionista que circularon por toda Europa. El maestro de Ávila o de la Sisla utilizó su Muerte de la Virgen (c. 1480) en la tabla del mismo tema que realizó para el retablo del monasterio jerónimo de Santa María de la Sisla (c. 1500. Museo del Prado) (figs. 10 y 11). Fernando Gallego, asimismo, usó un grabado del maestro centroeuropeo en la pintura titulada Cristo camino del Calvario (c. 14801490. Col. Masaveu). Los grabados po-

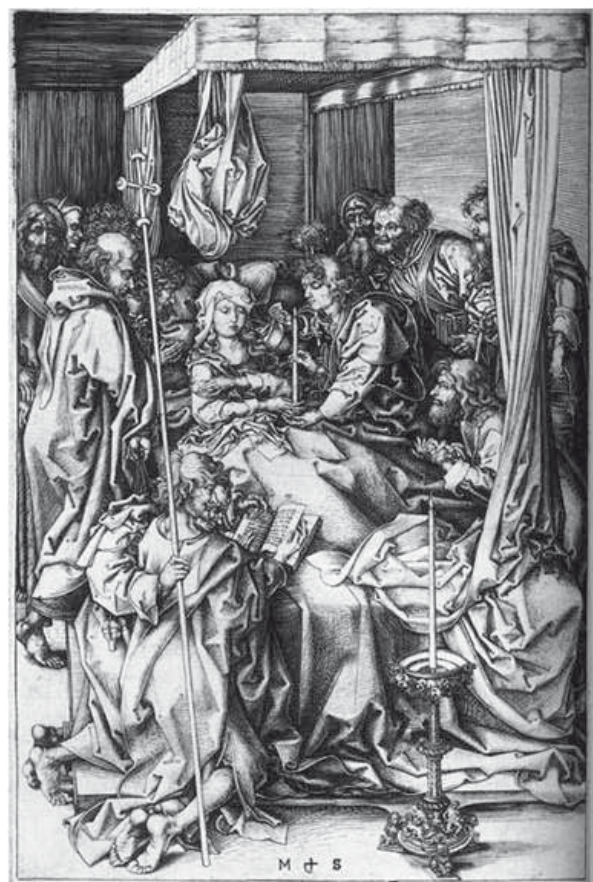

Fig. 10. Martín Schongauer, Muerte de la Virgen, ca. 1480 (London, The British Museum, 1910-212-295).

dían emplearse en más de una ocasión, a modo de mera reproducción o como traslación más libre del modelo original. Manteniendo la misma dinámica, el taller de Gallego acudió nuevamente al grabado centroeuropeo y a las variantes derivadas del mismo en la tabla de la misma temática de la iglesia de Santa María de Trujillo y el cercano maestro Bartolomé en la tabla del retablo de Ciudad Rodrigo $^{149}$. De nuevo, los nombres mencionados exteriorizan la casuística de una realidad más amplia.

\section{B) Reconocimiento de autoríal Prestigio de una obra}

No obstante, en una dinámica que fue adquiriendo peso en el trascurso del siglo $\mathrm{XV}$, los talleres junto a estos repertorios comunes fueron atesorando otros propios

${ }^{147}$ Los gustos "artísticos" de Columbus han merecido exposiciones monográficas: M. MCDONALDS, La colección de estampas de Hernando Colón (1488-1539). Coleccionismo en la era del descubrimiento, Madrid, 2004.

${ }^{148}$ Vid. A.W. DOTSETH, "Maestro Bartolome's use of prints in the altarpiece of Ciudad Rodrigo", Fernando Gallego and his workshop. The altarpiece from Ciudad Rodrigo, London, 2008, pp. 117-147.

${ }^{149}$ Sobre el uso variado de los grabados A.W. DOTSETH, op. cit., 2008, pp. 140-143 y 302 y ss. 


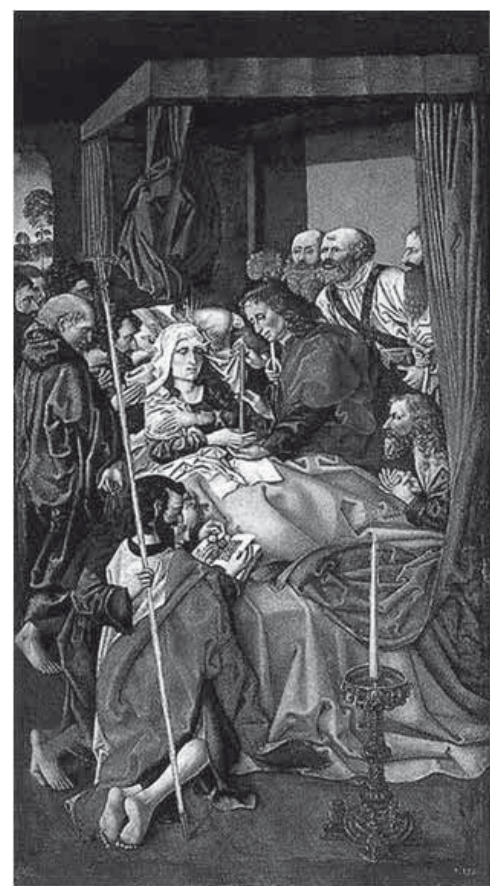

Fig. 11. Maestro de Ávila, Muerte de la Virgen, ca. 1500 (Museo del Prado). convertidos en un símil de estilo-firma o copyright del maestro ${ }^{150}$. El valor concedido a estos dibujos se especifica en su cesión -como bien preciado- a los herederos en caso de fallecimiento ${ }^{151}$ o en los litigios celebrados con motivo de apropiaciones injustificadas de los citados materiales. El pintor Gerard David, y acudimos a un caso harto conocido, protagonizó uno de los juicios más renombrados tras haberse adueñado de las cajas de bocetos de otro pintor a modo de pago por una deuda pendiente ${ }^{152}$. La cita revela el aprecio dado a estos repertorios y nos sitúa en un nuevo uso -nuevo aunque intrincado a lo anterior- de las copias: el reconocimiento de un maestro y, por extensión, de una obra afamada.

Correspondía al maestro crear un modelo del que podían derivar numerosas variantes o repeticiones. Sin embargo, las circunstancias de las mismas fueron múltiples al realizarse tanto del original como de los dibujos preparatorios, de forma directa o usando medios que facilitaban su reproducción mecánica ${ }^{153}$ y de manera mimética o con alteraciones incluyendo la reelaboración del original $^{154}$. Asimismo, las variantes podían derivar directamente del maestro o de miembros de su taller.

Tales prototipos, en el caso de las imágenes religiosas, mantenían su uso devocional y catequético característico a la par que incorporaban en su resolución una especie de estilo-firma que un público interesado podía reconocer y, sobre

${ }^{150}$ Algunas de estas cuestiones son abordadas por J.C. WILSON, Painting in Bruges at the close of the Middle Ages. Studies in Society and Visual Culture, Pennsylvania, 1998.

${ }^{151}$ R. SCHELLER (op. cit., 1995, p. 10) plantea una sugerente reflexión sobre el tema.

${ }^{152} \mathrm{El}$ contencioso terminó con la devolución de los bocetos a su propietario Ambrosius Benson, a cambio de su colaboración temporal en el taller de David (C. HARBISON, op. cit., [1995] 2007, p. 73.).

${ }^{153}$ Un buen maestro podía copiar a mano alzada sin dificultad, pero para acelerar las copias y conseguir mejor verosimilitud se podía acudir a varios métodos de transferencia mecánica -revelados, en algún caso, en los análisis actuales de las pinturas- como el calco perforado o la plantilla (S. CABALLERO ESCAMILLA, op. cit., 2006, p. 29). Lo anterior no excluye el uso de procedimientos más sofisticados como instrumentos geométricos y espejos cóncavos (H. MUND, op. cit., 2009, p. 191). Tampoco faltan las cuestiones de índole más legal ya que, en puntuales casos, se exigía el permiso del propietario y contar con un maestro especializado en esta labor (P. SILVA MAROTO, op. cit., 2000, p. 28).

${ }^{154}$ La situación trasciende los propios límites del trabajo artístico ya que diferentes hipótesis sobre la dependencia primigenia de ciertas tablas o retablos estriba en saber si copian originales, dibujos de taller o reelaboraciones de miembros integrantes del taller. Vid. S. NASH, op. cit., 2009, pp. 87-101. 
todo, demandar ${ }^{155}$. Precisamente, el público demandante está detrás de la calidad de las copias. Un encargo preciso podía obligar al trabajo del maestro o de los discípulos más aventajados; mientras que las obras realizadas para el mercado libre justifican la mayor presencia del taller. Tales copias se realizaron tanto en vida del maestro como después de la muerte del mismo, y tanto en el propio obrador como por artistas con ninguna relación con el maestro, pero que convencidos de la buena acogida de su estilo lo imitaron no descartándose inclusive las falsificaciones ${ }^{156}$.

Cotejamos esta múltiple realidad en la pintura de los llamados primitivos flamencos. Estudios recientes parecen otorgar a los pinceles de El Bosco la tabla -firmada- del Carro de Heno (1500-1505) depositada en el Monasterio de El Escorial. En este caso, la mímesis con la obra del Museo del Prado es claramente adverti$b^{1 e^{157}}$. El Bosco tuvo, asimismo, numerosos seguidores que interpretaron sus obras de forma literal o libre como reflejan las tablas dedicadas al Infierno (c. 1530-1540. Madrid, Col. Caja Madrid) o al Juicio Final (mediados siglo XVI. Tudela. Museo. Palacio Decanal) realizadas por sendos imitadores bosquianos ${ }^{158}$. El gusto hacia su pintura, fomentado en el siglo XVI por la moda hacia lo extravagante o extraordinario de la cámara de las maravillas, determinó que ese ansia favoreciera inclusive las falsificaciones. No es casual que Felipe de Guevara al hablar en sus Comentarios de la pintura (1560) de asentadas prácticas de falsificación, como el ahumado de las pinturas bajo las chimeneas para simular antigüedad, citara expresamente las copias fraudulentas de tablas de El Bosco:

"Ansi -expresa Guevara- vienen a ser infinitas las pinturas de este género selladas con el nombre de Hierónimo Bosco, falsamente inscripto, en las quales a él nunca le pasó por el pensamiento poner las manos sino el humo y corto ingenio ahumándolas a las chimeneas para darlas autoridad y antigüedad" 159 .

La obra del maestro Roger van der Weyden puede suscribir las mismas coordenadas ${ }^{160}$. Su composición sobre San Lucas pintor de la Virgen (c. 1435. Museum

${ }^{155}$ Una interesante reflexión sobre estos aspectos ligados al marketing de estas obras, a la gestión de marca -adaptación de gusto e identidad de producto- y el nicho de mercado en A. VERGARA, “¿Quién era Patinir? ¿Qué es un Patinir?”, Patinir. Estudios y catálogo crítico, Madrid, 2007, pp. 29-45; y H. MUND, op. cit., 2009, p. 190.

${ }^{156}$ Conocemos, por ejemplo, que el taller de Van Eyck estuvo en activo más de diez años después de su deceso (Jan Van Eyck, 2009, p. 45).

${ }^{157}$ P. SILVA MAROTO, op. cit., 2000, p. 27.

${ }^{158}$ En el comentario de ambas tablas B. FRANSEN reflexiona sobre los diversos modos empleados en las copias de los originales de El Bosco ("El Juicio Final”, Imitador de El Bosco y "El Infierno", Seguidor de El Bosco, Erasmo en España, 2002, pp. 262-263).

${ }^{159}$ F. de GUEVARA, Comentarios de la pintura, discurso y notas A. PONZ, Madrid, 1788, p. 42.

${ }^{160} \mathrm{H}$. MUND ya ha señalado las razones explicativas de las abundantes copias de sus obras: una dilatada carrera -llegó a tener casi dos generaciones de aprendices-; su fama en vida, dentro y fuera de los límites del mundo flamenco; la buena dirección del taller mantenido hasta 1514; y la creación de acertadas composiciones devocionales (op. cit., 2009, p. 190). 
of Fine Arts Boston) realizada para la guilda de pintores de Bruselas conformó un prototipo requerido por otras guildas. La crítica actual coincide en considerar que las copias hoy conservadas en Munich y San Petersburgo, atribuidas respectivamente a los llamados maestros de la Leyenda de Santa Catalina y del Follaje Bordado, debieron salir del taller del propio maestro en los tiempos que, ya muerto éste, lo regentaba su hijo.

Encontramos una mayor diversidad de opciones en las reproducciones de su célebre Descendimiento (c. 1430-1435. Museo del Prado, Madrid), realizado inicialmente para la cofradía de los ballesteros de Lovaina ${ }^{161}$. La fama inmediata de la obra determinó que las copias empezaran en vida del maestro. Apenas diez años después de su terminación, un noble de la localidad encargó una copia como parte central de un tríptico funerario (Tríptico Edelheere. c. 1443, Iglesia de San Pedro de Lovaina $)^{162}$. La reputación de la pieza fue extendiéndose en el transcurso de la centuria ${ }^{163}$. El llamado Maestro de San Bartolomé, en los umbrales del siglo XVI, realizó varias versiones del tema: unas más miméticas (c.1500. 227x210 cm. M.Louvre) y otras a pequeña escala y con más licencias (c. 1500. Nacional Gallery London. $75 \times 47 \mathrm{~cm})^{164}$. Los ejemplos terminaron por incluir significativas variantes como el añadido de un paisaje de fondo (Joos von Cleve, Descendimiento de la cruz, c. 1518-1520. Philadelphia Museum of Art y Seguidor de R. van der Weyden, Descendimiento de la cruz, Amsterdam, Christie's 9 de mayo de 2001, $\mathrm{n}^{\circ} 103$ ), alterando radicalmente la investigación plástica de la pieza, o la transformación de sus personajes. De tal forma, encontramos tablas donde Nicodemo aparece convertido en un San Lucas ${ }^{165}$.

Los métodos de trabajo significados fueron mantenidos, asimismo, por maestros de otros ámbitos. A modo de ejemplo, mencionamos que el prototipo de la Piedad Desplà de Bartolomé Bermejo tuvo sus correspondientes epígonos en miembros

${ }^{161}$ Sobre la compra del original por María de Hungría, su exposición inicial y la cuantificación de la venta vid. P. SILVA MAROTO, "El Descendimiento de Roger van der Weyden", Felipe II, mecenas de las artes, Madrid, 1999, p. 351.

${ }^{162}$ No es el único caso; aunque la mayor actividad de las copias aconteció entre 1464 y 1514 cuando el taller era llevado por sus directos descendientes, no descartándose la firma de contratos para estas actividades (H. MUND, op. cit., 2009, p. 194).

${ }^{163}$ Tales prácticas se mantuvieron en uso durante el siglo XVI; en este sentido, siempre es recurrente mencionar la copia del Políptico de San Bavón de Van Eyck que Felipe II encargó a Michel Coxcie, tras la petición de permisos a los canónigos de Gante que impusieron la condición de no mover el original de la capilla donde estaba colocado. Ciertamente, era la mejor alternativa a los infructuosos intentos de poseer la obra original. Vid. F. CHECA CREMADES, "Copia del retablo de los hermanos Van Eyck, Adoración del Cordero Místico”, Felipe II, mecenas de las artes, pp. 478-479.

${ }^{164}$ El maestro de San Bartolomé estuvo activo entre 1480 y 1510 (V. NIETO ALCALDE, El Descendimiento de Roger van der Weyden, Madrid, 2002, p. 19).

165 Todos estos aspectos vinculados a la vida posterior de la obra de Weyden en el citado trabajo de $\mathrm{H}$. MUND, op. cit., 2009, pp. 186-199. 
del taller ${ }^{166}$ (fig. 12) o que el maestro aragonés Grañén repitió, con pocas variantes, su prototipo de Virgen entronizada en diferentes retablos ${ }^{167}$. Los hechos de los que hablamos, pues, tuvieron una dimensión europea y resultaron afines a toda la estética tardogótica.

Nuevamente, la originalidad convive con la afición a las copias; mas conviene insistir en la polivalencia adquirida por las copias en este apartado al unir un uso devocional con una mirada de entendido que apreciaba el estilo y la autoría de la obra. Esta dinámica precisamente pudo determinar que, en algunos casos, el encargante de las copias fuera el mismo propietario con objeto de publicitar una imagen política o representativa ${ }^{168}$ o de realizar regalos -la diplomacia del regalo-, a modo de orgullo de coleccionista parecido al que siglos

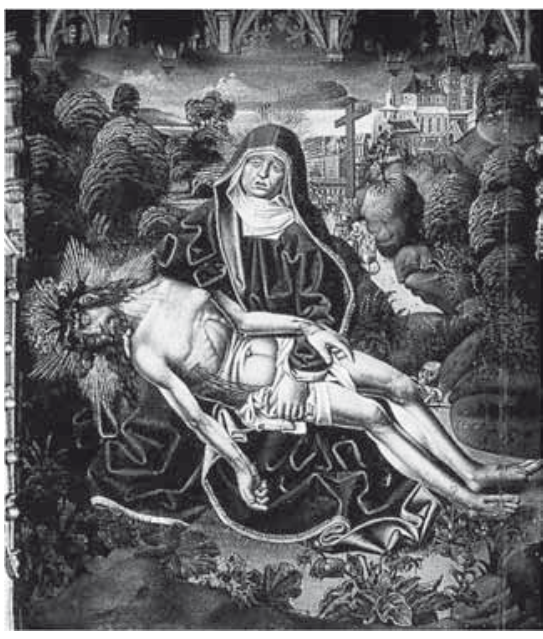

Fig. 12. Seguidor de Bartolomé Bermejo, Retablo portátil de la Piedad, san Francisco, san Sebastián, san Juan Evangelista y san Jerónimo (North Carolina Museum of Art). después exhibirá el archiduque Leopoldo Guillermo en las pinturas de gabinete realizadas por Teniers ${ }^{169}$.

\section{C) Copia con dimensión memorial}

La aludida dimensión devocional de los "artefactos" nos permite apreciar otro uso justificativo de las copias: la dimensión memorial. Evocación memorial extensible a ciudades - como Jerusalén-, edificios -desde la iglesia del Santo Sepulcro a la mezquita de Córdoba-y, en un mayor número, a imágenes. Hablamos tanto de imágenes de altar como -o sobre todo- de imágenes devocionales de pequeño formato que, como ha señalado uno de los grandes especialistas en el tema, nacen de una aparente paradoja: la necesidad del original para su existencia y, a su vez, su requerida independencia para poder cumplir su función. Imágenes que, vendidas mayoritariamente desde los santuarios con las indulgencias pertinentes, recibían sus correspondientes protocolos. En este caso, la 190-194.

${ }^{166}$ F. PAU VERRIÉ, "Bartolomé Bermejo, Piedad”, Bartolomé Bermejo y su época, Madrid, 2007, pp.

${ }^{167}$ M.C. LACARRA DUCAY, Blasco de Grañén, pintor de retablos (1422-1459), Zaragoza, 2003.

${ }^{168}$ Las copias del retrato del duque Felipe el Bueno realizadas a partir de un original del maestro Weyden parecen poder ilustrar esta práctica. Vid. T. HOLGER-BORHERT, The Age of Van Eyck. The mediterranean World and Early Netherlandish Painting 1430-1530, Gante, 2002, p. 247.

${ }^{169}$ La intención otorgada a los mismos en el catálogo M. DÍAZ PADRÓN y M. ROYO-VILLANOVA (com.), David Teniers, Jan Brueghel y los gabinetes de pinturas, Madrid, 1992. 
materialidad solía ocupar un lugar secundario frente a su valor apotropaico e inclusive taumatúrgico ${ }^{170}$.

El uso de estas prácticas se incrementó notablemente en las postrimerías del Medievo pero la casuística que les define es anterior. Recordemos, a modo de ejemplo, la existencia de libros de modelos previos como el Álbum de Villard d'Honnecourt (c.1220-1240) ${ }^{171}$, el valor referencial de la Maestà de Duccio en la de su discípulo Simone Martini y el de ésta en la de Lippo Memmi en San Gimigniano ${ }^{172}$; el empleo de la portada del Sarmental de la catedral de Burgos como referencia visual/ jerárquica en la entrada del templo burgalés de Sasamón ${ }^{173}$; o la temprana reproducción, parcial o íntegra, del contenido del Codex Calixtinus $^{174}$.

Lo comentado obliga a un replanteamiento múltiple de la obra de arte, subraya la dificultad de regirse por criterios meramente estilísticos ya que, como hemos visto, a veces deliberadamente se emplean cronologías retardatarias, incide en el valor de la materialidad propia de la obra y enfatiza el valor de su interpretación en los términos de la cultura visual del período.

\footnotetext{
${ }^{170}$ En esta configuración de prototipos, apreciamos una cierta tendencia a usar formas antiguas para darles una validez intemporal. Vid. el texto ya mencionado de H. BELTING, op. cit., [1990] 2009.

${ }^{171}$ El Álbum del arquitecto francés Villard de Honnecourt incluye entre sus folios, además de sus características figuras geométricas o utillaje técnico, iconogramas de conceptos morales -el orgullo tal como cae por tierra. La humildad-cuya silueta hallamos copiada de /reproducida en diferentes portadas de catedrales francesas. Vid. A. ERLANDE-BRANDEBURG et alii (eds.), Villard de Honnecourt. Cuaderno siglo XIII. A partir del manuscrito conservado en la Bibliothèque Nationale de Paris ( $\left.{ }^{\circ} 19093\right)$, Madrid, 1991.

${ }^{172}$ Simone Martini al pintar su Maestà (1315) imitó la representación que había hecho su maestro de la composición, incluyendo el orden del santoral patrono de Siena. La popularidad del tema determinó que éste se repitiese en el palacio público de San Gimigniano. Lippo Memmi añadió en su Maestà (1317-1318) un nuevo eslabón a la cadena con las adaptaciones que exigía el encargo relativo a sus donantes. Vid. J. T. PALEOTTI y G.M. RADKE, El Arte en la Italia del Renacimiento, Madrid, [1997] 2002, pp. 111-114.

${ }^{173}$ La diferencia entre ambas no estriba en la iconografía o en la composición, sino en la dispar pericia del maestro o taller, mas con su emulación se busca la evocación y el prestigio de un notable centro eclesiástico. Un último acercamiento a esta pieza escultórica en R. SÁNCHEZ AMEIJEIRAS, "La portada del Sarmental de la catedral de Burgos. Fuentes y fortuna", Revista d'Art, 1 (2001), pp. 161-198.

${ }^{174}$ L. FERNÁNDEZ FERNÁNDEZ, “[...] cosas tan deshonestas y feas que valiera harto más no haberlo escrito. Avatares y memoria del Codex Calixtinus", J.C. ASENSIO (coord.), El Codex Calixtinus en la Europa del siglo XII. Música, Arte, Codicología y Liturgia, Madrid, 2011, pp. 186-190.
} 